\title{
Обзор: конференции
}

УДК 821.161 .1

ББК $83.3(2 \mathrm{POC}=\mathrm{PYC})$

DOI 10.22455/2619-0311-2020-1-201-255

\section{Владимир Викторович, Альбина Бессонова VII Летние чтения в Даровом*}

\section{Vladimir Victorovich, lbina Bessonova VII Summer Readings in Darovoye}

Об авторе: Владимир Александрович Викторович, доктор филологических наук, профессор кафедры литературы Государственного социально-гуманитарного университета (Коломна).

E-mail: VA_Viktorovich@mail.ru

Об авторе: Альбина Станиславовна Бессонова, кандидат филологических наук, ведущий научный сотрудник Государственного социально-гуманитарного университета (Коломна).

E-mail: abessonova13@mail.ru

Аннотация: Предлагается обзор выступлений на «Летних чтениях в Даровом», проходивших в седьмой раз в г. Зарайске (Московская область) и усадьбе Достоевских в деревне Даровое. Обсуждались две темы: рецепция творчества Достоевского и поиск архивных документов, открывающих контекст ранней биографии и источники творчества автора «Братьев Карамазовых». Итоговая дискуссия была посвящена перспективам формирующегося музея-заповедника на земле детства писателя.

Ключевые слова: история рецепций, понимание и толкование, усадьба Достоевских Даровое, новые архивные документы, создание музея-заповедника.

Для цитирования: Викторович B.A., Бессонова А.C. VII Летние чтения в Даровом // Достоевский и мировая культура. Филологический журнал. 2020. № 1 (9). С. 201-255.

DOI 10.22455/2619-0311-2020-1-201-255

Мероприятие было организовано при финансовой поддержке РФФИ в рамках двух проектов: 18-012-90012 «Ф.М. Достоевский в русской критике. 1845-1881» и 18-012-90038 «Даровое Достоевского: документальные источники, биография, творчество» / The event was held with financial support from Russian Foundation for Basic Research (RFBR) as part of two projects: 18-012-90012 "F.M. Dostoevsky in Russian Criticism. 1845-1881" and 18-01290038 “Dostoevsky’s Darovoe: Documentary Sources, Biography, Work”. 
About the author: Vladimir A. Victorovich, Doctor of Philological Sciences, Professor of the Department of Literature at the Kolomna State University of $\mathrm{Hu}$ manities and Social Studies (Kolomna).

E-mail:VA_Viktorovich@mail.ru

About the author: Albina S. Bessonova, Candidate of Philological Sciences, Leading Research Associate at the Kolomna State University of Humanities and Social Studies (Kolomna).

E-mail: abessonova13@mail.ru

Abstract: The article presents an overview of the seventh edition of Darovoe Summer Readings, held in Zaraysk (Moscow region), and in Dostoevsky's estate in the village of Darovoe. The Readings focused on two topics: the reception of Dostoevsky's work, and the search for archival documents about the context of the early biography and the creative sources of the author of The Brothers Karamazov. The closing round table was dedicated to the perspective developments of the Museum in the land of the writer's childhood.

Key words: reception history, understanding and interpretation, Dostoevsky's, Darovoe, estate, new archival documents, creating a Museum.

For citation: Bessonova A.S., Victorovich V.A. VII Summer Readings in Darovoye. Dostoevsky and World Culture, Philological journal, 2020, No 1(9), pp.201-255.

DOI 10.22455/2619-0311-2020-1-201-255

Летние чтения в Даровом по сложившейся традиции - тематические. На сей раз (30-31 августа 2019 г.) была заявлена тема «Достоевский: проблемы восприятия и толкования». Работали две секции: «Достоевский и читатели», а также «Усадьба Даровое в новом прочтении (по неизвестным документам)». Завершил конференцию круглый стол «Музей-усадьба Даровое: предложения к проекту».

\section{1. Достоевский и читатели}

Одна из современниц Ф.М. Достоевского заметила, что писатель страдал от того, что «его не понимали и перетолковывали». Вместе с тем та же мемуаристка признавалась, что и ей самой (дело было в 1873-1874 гг.) «всё трудней и трудней становилось сочувствовать и порой даже понимать его мысли» [Тимофеева, 1990, т. 2, с. 180]. Перипетии рецептивной истории, то приближающей, то отдаляющей нас от писателя и мыслителя, взялись обсудить участники секции «Достоевский и читатели» «VII Летних чтений в Даровом». 
Так, В.А. Викторович (Коломна) в докладе «Понять Достоевского» обратился к острой проблеме отторжения и разочарования в Достоевском читателей разного времени. По наблюдению одного из прижизненных критиков, Вс.С. Соловьева (пережившего относительно Достоевского и восторг, и отрезвление), значительная часть публики «просто боится его романов», ища облегчающего жизнь чтения, между тем как Достоевский собирает на своих страницах «всё, что только есть темного, больного, мучительного, безобразного в нашей общественной и личной жизни» [Соловьев, 1875, с. 1]. Замеченная еще полтора века назад достоевскофобия повторялась затем в разных вариациях. Знаменитую статью Михайловского «Жестокий талант» продиктовал страх «просто» мыслящего рационалиста перед открывшейся «непростой» иррациональной природой человека. Страх этот был знаком и такому читателю Достоевского, как И.С. Тургенев, который живо откликнулся на выступление Михайловского и добавил от себя сравнение Достоевского с маркизом де Садом. Замечательно при этом, что практически всех отрицателей до сей поры объединяет высокий эмоциональный градус высказываний, свидетельствующий о неконтролируемой захваченности «ужасным» Достоевским. Его идеи играют здесь не последнюю роль: их, когда талант писателя всё же признаётся, чаще всего противопоставляют созданным им художественным «картинам». Одной из кульминаций этого процесса были «Заметки о мещанстве» (1905) А.М. Горького, где Достоевский вкупе с Л. Толстым за их «проповедь терпения» были объявлены «злыми врагами жизни» [Горький, 1956, с. 388]. Традиция приписывать художнику смыслы, нужные обличителю, удивительно живуча, современная же деконструкция предоставляет изощренные методы расправы с автором. Следует признать, что нынешнему читателю понять Достоевского бывает ничуть не проще, чем полтора века назад. Полемика «за» и «против» христианской аксиологии сегодня вовсе не ослабла, а Достоевский как могучий ее выразитель остается на самом острие этой полемики.

С.А. Кибальник (Санкт-Петербург) в докладе «Достоевский глазами писателей XXI века» говорил об «отражениях» Достоевского в современной западной и русской литературе. Например, роман последнего Нобелевского лауреата Кадзуо Исигуро «Don’t Let me Go» («Не отпускай меня») - это, по его словам, может быть, и не новый Достоевский, но по силе и актуальности художественного высказывания явление, несомненно, конгениальное. Хотя, на первый 
взгляд, книга написана очень просто, но за счет мощного и жесткого замысла взмывает ввысь как на набоковской подкидной доске (по изысканному выражению докладчика). Гораздо более скромные результаты дают, как правило, попытки прямого обращения к образу Достоевского. Так, например, роман Максвелла Кутзее «The Master of Petersburg» (в русском переводе «Осень в Петербурге») это, по мнению докладчика, явная художественная неудача писателя. В русской литературе в последнее время были попытки как бы переписать роман Достоевского «Бесы». Не самую удачную из них, хотя и, безусловно, интересную, представляет собой роман Андрея Степанова «Бес искусства». Впрочем, и посвящен он более локальной теме. В этом плане более близким Достоевскому представляется роман Виктора Пелевина «Любовь к трем цукербринам», второе заглавие которого, как бы зашифрованное в тексте романа, - «Бесы-2». Он, конечно, гораздо более эзотеричен, чем «Бесы» Достоевского, и не всякому читателю по зубам. Однако переход от «Если Бога нет, то всё позволено» к идее о том, что людям проще убивать Бога, чем следовать десяти заповедям, по мнению докладчика, достаточно адекватно изображает «прогресс» современного человечества. В какой-то мере такое видение мира отвечает внутренним интенциям художественной мысли Достоевского, которая, впрочем, всё же немного более оптимистична.

В докладе О.В. Захаровой (Петрозаводск) «Кто назвал Достоевского гением?» был поставлен этот вопрос относительно русской печати. В мае 1845 года начинающий писатель отдал роман «Бедные люди» в альманах Некрасова «Петербургский сборник». Роман восхитил Григоровича, Некрасова, Белинского, Панаева и др. Слух о «новом Гоголе» разнесся по литературному Петербургу, но печатные отзывы о романе появились лишь в январе 1846 года. В январе - начале февраля молва превращалась в литературный факт. Задал интригу Белинский, предварив появление «Петербургского сборника» с «Бедными людьми»: «...наступающий год, - мы знаем это наверное, - должен сильно возбудить внимание публики одним новым литературным именем, которому, кажется, суждено играть в нашей литературе одну из таких ролей, какие даются слишком немногим. Что это за имя, чье оно, чем занимательно, - обо всем этом мы пока умолчим, тем более что всё это сама публика узнает на днях» [Белинский, 1955, т. 9, с. 407-408]. (Типичный маркетинговый ход, сказали бы сегодня). В полемике о Достоевском слово гений 
прозвучало в фельетонах Брандта и Булгарина. Критики «Северной пчелы» возмущались Белинским и его окружением («по городу разнесли вести о новом гении, г. Достоевском» [Булгарин, 1846, с. 107]), но те выдержали паузу и печатно не объявили Достоевского гением. Даже в рецензии на «Петербургский сборник» в мартовских «Отечественных записках» 1846 года Белинский несколько раз называет Достоевского «необыкновенным талантом», но определение «гениальный талант» присваивает только Гоголю, Пушкину и Лермонтову. И лишь его оппоненты, пытаясь разоблачить преувеличенность юного дарования, первыми произнесли ключевое слово (похожая история произошла тогда же с термином «натуральная школа»). Хулители Достоевского сочиняли трактаты о гениях, обсуждали различие между талантом и гением, давали свои классификации гениев. Полемика по поводу «Бедных людей» таким образом невольно поставила вопрос о гениальности автора романа.

А.И. Галицкий (Санкт-Петербург) представил доклад «Читательское восприятие повести “Двойник” от момента публикации до наших дней. Пример движения от негативного к позитивному». По мнению докладчика, проблема восприятия повести «Двойник» напрямую связана с тем, что для любого новаторства нужно время, чтобы улеглись первоначальные страсти. Интересно проследить, как менялось читательское отношение к шедевру молодого Достоевского на протяжении трех веков. Известно резюме Белинского, выраженное критиком на момент публикации повести: «Фантастическое в наше время может иметь место только в домах умалишенных, а не в литературе, и находиться в заведывании врачей, а не поэтов» [Белинский, 1955, т. 10, с. 41]. Пошел поток отрицательных отзывов, произведение приняли лишь единицы из читающей публики. Примерно с конца XIX века отношение к фантастическому литературному опыту Достоевского меняется. В 1886 году вышел роман шотландского писателя Роберта Стивенсона «Странная история Джекила и мистера Хайда», в основе которого также была тема двойничества. Стивенсон пошел по следам Достоевского, выражая мысль о том, что свет и тьма перемешаны внутри человека. Тем самым он «реабилитировал» предшественника в глазах новых читателей. Почти в то же время французским психологом и врачом Пьером Жане был предложен термин «диссоциация»: комплекс идей может отщепляться от основной личности и существовать независимо и вне сознания. C наступлением XX века стало понятно, что 
проблема расщепления сознания обостряется в кризисные моменты культурно-исторического развития. В одном из стихотворений Александра Блока прямо сказано: «Слишком много есть в каждом из нас неизвестных, играющих сил...» [Блок, 1997, т. 3, с. 27]. Существенный вклад в понимание «Двойника» внес Михаил Бахтин в своей монографии «Проблемы творчества Достоевского» (1929), а также ряд других авторов. Исследования начала XXI века прибавили новые краски в анализ «Двойника». Так, доцент кафедры нейро- и патопсихологии факультета психологии МГУ Игорь Кадыров в статье «“Двойник” Ф.М. Достоевского: попытка психоаналитической интерпретации» утверждает: «динамика отношений двух Голядкиных предстает как отношения вампира и жертвы» [Кадыров]. Исследователь отмечает, что тема двойничества имеет глубокие и древние корни в культуре, она отчетливо представлена и в религии, и в мифологии, и в фольклоре, и в современном искусстве. Весьма интересный взгляд на «Двойника» представил британский режиссер Ричард Айоади в одноименном художественном фильме 2013 года. «Идея очень интересная, - заявил он в интервью, - о человеческой уникальности, одиночестве и потерянности, когда вдруг появляется двойник» [Айоади, 2014]. «“Двойник” для своего времени был весьма новаторским произведением. Людям потребовалось много времени, чтобы оценить его по достоинству» [Айоади].

В докладе «Некрасов - читатель Достоевского» Т.П. Баталова (Санкт-Петербург) рассматривала переосмысление Некрасовым традиционных погодных образов в социальном плане («Перед дождем», 1846; цикл «О погоде», 1859-1865 и др.) как момент диалога с погодными образами «Двойника» Достоевского (1845), отмеченными глубоким психологизмом. В контексте творческого диалога анализировались сцены «На берегу большой реки» «Преступления и наказания» Достоевского (1866) и встреча княгини М.Н. Волконской с мужем на каторге в «Русских женщинах» Некрасова (1873), «Записок из подполья» Достоевского (1863) и «Суда» Некрасова (1867).

В докладе «Творческий диалог Некрасова и Достоевского» Г.В. Федянова (Санкт-Петербург) обратила внимание на особую функцию «литературных похищений» в сцене избиения лошади в «Преступлении и наказании». Было отмечено, что этот эпизод из сна Раскольникова является звеном творческого диалога Достоевского как с Некрасовым, так и с Чернышевским. Некрасовская избитая 
клячёнка «как-то боком», но пошла («О погоде», 1859). Достоевский предлагает свое видение результата обреченности на «непосильную ношу»: венчающая живописную картину воза вульгарная баба в кумачах могла быть воспринята читателем как российская альтернатива озорной француженки «в розовом» из культового романа «Что делать?» (1863).

Дебют Достоевского в восприятии Некрасова был рассмотрен в докладе Д.А. Июдина (Петрозаводск) «Достоевский как прототип незавершенной повести Некрасова». Докладчик выделил три варианта прототипичности образа Глажиевского-Достоевского в повести. 1) Представляя Достоевского как писателя и как историческое лицо, Некрасов выступает как мемуарист, он вспоминает события, которым был свидетель. В этих эпизодах повести преобладает документализм, автор использует факты биографии писателя, оказавшегося в эпицентре петербургской литературной жизни 1845 года. 2) Некрасов трактует художественный опыт раннего Достоевского, узнавая самого автора в Макаре Девушкине и Голядкине. 3) Достоевский предстает в повести персонажем сплетен, слухов, фельетонов Панаева, послания Белинского Достоевскому. Это сатирический, «фельетонный», утрированный образ юного гения, не готового к данной роли, несостоятельного как личность, а потому высмеянного окружением Белинского. Причиной, из-за которой Некрасов не завершил свой замысел, Д.А. Июдин видит в том, что история несостоявшегося гения вышла под его пером слишком прямолинейной и назидательной. Поначалу тема увлекла Некрасова, но позже он потерял к ней интерес. В образе Глажиевского отсутствует сложность, автор разоблачает своего героя как недалекого, падкого на лесть, неискреннего человека. Такая установка и привела Некрасова к художественной неудаче, хотя миф о личностной несостоятельности Достоевского продолжил свое существование и в последующих поколениях известного рода читателей.

А.П. Дмитриев (Санкт-Петербург) представил доклад «К оценке “Бедных людей” и “Двойника” Ф.М. Достоевского в семье Аксаковых (по переписке В.С. Аксаковой и М.Г. Карташевской)». В семье Аксаковых узнали о появлении «нового Гоголя» из письма петербургской кузины М.Г. Карташевской к В.С. Аксаковой от 31 октября - 5 ноября 1845 г. ${ }^{1}$ [Пушкин. Лермонтов. Гоголь, 1952, с. 674-676], на ко-

1 РО ИРЛИ. Фонд А.Н. Марковича № 10639. Л. 104 - 104. Об. 
торое та скептически откликнулась 12 ноября: «...я думаю, это вроде Бенедиктова, которого также вначале называли Пушкиным»² $[$ Пушкин. Лермонтов. Гоголь, 1952, с. 676]. Аксаковы еще до знакомства с произведениями Достоевского были предубеждены против него. Сыграли роль, во-первых, преувеличенные, на их взгляд, похвалы молодому писателю, известному лишь в узком кругу петербургских литераторов; во-вторых, несколько ревнивое отношение к толкам, имевшим связь с высоко ценимым Гоголем, а главное - в их глазах Достоевский выдвигался западнической партией во главе с Белинским как бы в противовес Гоголю с его «славянофильским духом» (так обстоятельства внелитературного, но при том «партийного» свойства способны предопределять рецепцию художественного произведения). В гостиной Карташевских «Бедные люди» были прочтены вслух братом хозяйки Н.Т. Аксаковым в конце января - начале февраля, а в Абрамцеве - в середине февраля, и также в присутствии всей семьи. Этот роман, так же как и повесть «Двойник», как известно, вызвал в целом негативную оценку С.Т. Аксакова и его сыновей Константина и Ивана, что отразилось прежде всего в известной рецензии К.С. Аксакова. Он критиковал роман Достоевского прежде всего за «филантропическую тенденцию» [Три критические статьи..., 1995, с. 138] - стремление пробудить сострадание к беднякам, то есть за внеположные, по убеждению рецензента, истинному искусству дидактические цели. О том же, упоминая социальный роман Эжена Сю, писала и М.Г. Карташевская. Упрек В.С. Аксаковой в отсутствии, по ее словам, «освежительных высоких наслаждений художеством» ${ }^{3}$ [Пушкин. Лермонтов. Гоголь, 1952, с. 680] выливается под пером ее брата в целую диатрибу о том, что роман Достоевского «оставляет впечатление тяжелое, чего никогда не может быть при создании истинно художественном» - в отличие от «глубокой, примиряющей красоты» [Три критические статьи..., 1995, с. 138], присущей гоголевской «Шинели». Объясняют известную резкость в суждениях корреспонденток контекстные сведения об их круге чтения в рассматриваемый период. Так, Мария от «Бедных людей» сразу переходит к восторженной оценке «Рождественской песни в прозе» Ч. Диккенса: «Как прекрасно! Какая живая, глубокая любовь к своим собратьям и как превосходны все малейшие подробности его рассказа»; Вера в противовес «тяжелому» роману Достоевского пишет

2 РО ИРЛИ. Фонд А.Н. Марковича № 10615. Л. 125 об. - 126.

3 РО ИРЛИ. Фонд А.Н. Марковича № 10616. Л. 18 - 19. 
об «ободряющем» романе шведской писательницы-феминистки Фредрики Бремер «В Далекарлии»: «...удивительно как хорошо, с каким удовольствием я это читаю, в ней есть что-то ободряющее» ${ }^{4}$. Основным эстетическим критерием для сестер был, так сказать, эмоциональный тонус литературного произведения: они ценили теплый юмор, жизнеутверждающие ноты и избегали тональности, навевающей уныние (привычный и впоследствии читательский упрек в адрес «тяжелого» Достоевского). Прочитанный сестрами в конце марта «Двойник» разочаровал их еще больше, чем «Бедные люди». Но негодование Веры: «Такого подражания Гоголю, бездушного и даже наглого, и вообразить нельзя» ${ }^{5}$ [Пушкин. Лермонтов. Гоголь, 1952 , c. 680] - Мария смягчала: повесть «несносно растянута <...> но мне кажется, и в ней виден талант» ${ }^{6}$. Неприятие ранних произведений Достоевского в переписке сестер было обставлено существенными оговорками: «согрето чувством», «видна любящая душа», «с большим достоинством». Очевидно, что читательские вкусы прямо высказавшихся о Достоевском В.С. и К.С. Аксаковых и М.Г. Карташевской были сформированы романтической эстетикой, теорией «бесцельного» творчества; однако «Бедные люди» и «Двойник» в их глазах всё же обладали известным художественным достоинством, чего (как бы «скрепя сердце») не могли игнорировать в семье Аксаковых. Ее представители были не лишены эстетической чуткости, приходившей в противоречие с заранее заданным настроем.

А.В. Индзинская (Коломна) в докладе «“Куклы” и “человечки” Ф.М. Достоевского (опыт чтения Е.А. Штакеншнейдер)» рассмотрела ситуацию в прижизненной критике Достоевского, когда непонимание собратьев по литературе искупалось возрастающим признанием читателей и их искренней любовью. Таким читателем была Елена Андреевна Штакеншнейдер, дочь известного архитектора. В своем дневнике она зафиксировала выступления писателя и реакцию на них петербургской публики, дала описание его внешности, привычек, манеры чтения и разговора. Существенной была и попытка критической оценки художественного мира писателя. В письме к Я.П. Полонскому она пишет об авторе нового романа «Униженные и оскорбленные»: «Он создал сам себе, не по образу Божию, а по своему собственному образу человечков, и видит, и мы все видим,

\footnotetext{
4 РО ИРЛИ. Фонд А.Н. Марковича № 10616. Л. 15 об.

5 РО ИРЛИ. Фонд А.Н. Марковича № 10616. Л. 18 - 19.

6 РО ИРЛИ. Фонд А.Н. Марковича № 10640. Л. 23 об.
} 
что они в самом деле человечки, хоть и не похожи на нас» ${ }^{7}$. Найденный Штакеншнейдер образ «человечков» (существ одушевленных и наделенных отдельным от авторского голосом) принципиально отличался от образа «кукол», введенного тогда же в литературную критику Е.Ф. Зариным, доказывавшим, что характеры героев романа «избавлены от всех условий человеческого правдоподобия» [Зарин, 1862 , с. 34]. Кропотливая и многолетняя работа постижения «истинного дарования» Достоевского, в подтексте которого проступала христианская аксиология, поставила Е.А. Штакеншнейдер в первые ряды сочувственной Достоевскому армии читателей, численность которой постоянно возрастала вопреки недоброжелательству критики.

Доклад Н.Н. Богданова (Москва) «Достоевские - читатели Достоевского» был в основном посвящен осмыслению читательского опыта внука писателя А.Ф. Достоевского, прошедшего путь от индифферентности до служения своему великому деду. К великому и горькому нашему сожалению безвременный уход из жизни Николая Николаевича Богданова прервал его работу неутомимого исследователя рода Достоевских, и нам остается надеяться, что текст его доклада, как и другие не увидевшие свет работы еще появятся в печати.

В докладе В.Н. Абросимовой «Французский корреспондент А.Г. Достоевской» была представлена переписка вдовы писателя с А.С. Сувориным и молодым ученым Гастоном Луага, одним из первых взявшихся за медико-психологическое исследование жизни и творчества Достоевского [Loygue, 1904]. 23 января 1903 года А.Г. Достоевская ответила на вопросы молодого француза, отправила ему книги, которые он просил прислать, составила список из 35 работ, необходимых для завершения его диссертации. Письма переведены с французского языка С.А. Савостиной и вводятся в научный оборот впервые.

В центре доклада Г.С. Прохорова «Достоевский в критике читателей-евреев» - оценка творчества писателя, данная Аркадием Ковнером и Софией Лурье. Материалом послужили как личные письма указанных корреспондентов к Достоевскому, так и литературно-критическая рубрика «Литературные и общественные курьезы», которую вел Ковнер в газете «Голос» и которая в значительной

7 РО ИРЛИ. Архив Я. П. Полонского. № 12612. Штакеншнейдер Елена Андреевна. Письма (93) Полонскому Якову Петровичу. Автографы. 1861-1897. Л. 4 об. - 5. 25. 
мере была нацелена на полемику с «Гражданином», редактируемым Достоевским. Были продемонстрированы: а) интерес еврейских публицистов к творчеству и общественной позиции Достоевского; б) попытки интерпретировать творчество Достоевского, его сюжетику и персонажную систему через нормы поэтики еврейской литературы; в) границы такой интерпретации и попыток экспликации культурного трансферта (по выражению докладчика) между русской и еврейской литературой и культурой.

Т.С. Карпачева (Москва) в докладе «Набоков как читатель Достоевского: восприятие вопреки отрицанию», опираясь на работы [Берберова, 2001; Карякин, 1989; Сараскина, 1993; Горковенко, 1999; Шепелев, 2003; Шадурский, 2004], рассмотрела восприятие художественного слова Достоевского в романе «Лолита». По мнению докладчика, сама теория Гумберта о нимфетках представляет собой «вариант» теории Раскольникова: якобы есть дети (не все!), несущие в себе демоническое начало, перед которыми «не в силах» устоять некоторые «очарованные странники» (педофилы на языке Гумберта) и, соответственно, в отношении которых допустимы преступления сексуального характера, поскольку «странник» не может сопротивляться охватившей его страсти. Ярче всего аллюзии на художественные тексты Достоевского прослеживаются в конце романа - в сцене несостоявшегося покаяния Гумберта. «В минуту метафизического любопытства» Гумберт обращается «к умному <...> духовнику, в руки которого <он> передал серое безверие протестанта» [Набоков, 2007, с. 317]. Этот духовник явно соотносится с образом епископа Тихона из романа «Бесы». Как для Ставрогина, так и для Гумберта путь покаяния оказывается недостижим. В его несостоявшейся исповеди прослеживается также вопрос, напоминающий слова Ивана Карамазова: «...какое бы духовное утешение я ни снискал, <...> ничто не могло бы заставить мою Лолиту забыть всё то дикое, грязное, к чему мое вожделение принудило ее. Поскольку не доказано мне <...>, что поведение маньяка, лишившего детства северо-американскую малолетнюю девочку, Долорес Гейз, не имеет ни цены ни веса в разрезе вечности - поскольку мне не доказано это (а если можно это доказать, то жизнь - пошлый фарс), я ничего другого не нахожу <...>, как унылый <...> паллиатив словесного искусства» [Набоков, 2007, с. 317-318]. Здесь мы видим «перевернутый» вопрос Ивана Карамазова: «зачем мне ад для мучителей, что тут ад может поправить, когда те уже замучены?» [Достоевский, 1972- 
1990, т. 14, с. 223] - в интерпретации Гумберта: зачем мое покаяние и что оно изменит в вечности, если Лолита никогда не сможет забыть всё то «мерзкое и гнусное»? В докладе прослеживались также иные аллюзии на художественные произведения Достоевского в романе «Лолита». Набоков явно не мог пройти мимо Достоевского, о чем говорит совпадение ряда сюжетов и образов, воспринятых им. Роман «Лолита» впитал в себя художественное слово Достоевского вопреки отношению автора к его творчеству. Примеры подобного рода «вопрекизма» в рецептивной истории особенно ценны, свидетельствуя о возможностях ослабления центробежных «сил предрассужденья» в эстетическом поле (что было продемонстрировано также и в докладе А.П. Дмитриева на другом материале).

Д.И. Яндыбаева (Москва) в докладе «И.С. Шмелев как читатель Ф.М. Достоевского: отголоски романа “Братья Карамазовы” в романе “Лето Господне” обратила внимание на то, что образ главного героя шмелевского романа, Вани, соотносится с образом Алеши Карамазова, однако автор наделяет его и некоторыми чертами Ивана. Отношение Вани к его воспитателю Горкину напоминает отношение Алеши к старцу Зосиме. Ответ Горкина на вопрос Вани, воротится ли умерший папенька, в свою очередь, похож на ответ Алеши Карамазова на вопрос Коли Красоткина: «...неужели и взаправду религия говорит, что мы все встанем из мертвых, и оживем, и увидим опять друг друга, и всех, и Илюшечку? - Непременно восстанем, непременно увидим...» [Достоевский, 1972-1990, т. 15, с. 197]. Сон, который видит Ваня, в то время как умирает его отец, - это, по наблюдению докладчика, аллюзия на сон Алеши Карамазова после смерти старца Зосимы, когда он видит Христа, старца и ангелов на брачном пиру в Кане Галилейской. В романе Шмелева слышится отзвук вопроса, который поднимает Иван у Достоевского, - это вопрос о попущении Богом страданий. У Шмелева этим вопросом задается маленький Ваня, который Великим постом, глядя на Распятие, размышляет: «Мучается, Сын Божий! А Бог-то как же... как же Он допустил? Чувствуется мне в этом великая тайна - Бог» [Шмелев, 1998, т. 4, с. 18]. Мир Вани, конечно, более гармоничен, чем мир Ивана Карамазова, но мы видим, что и ему уже надо «мысль разрешить», что и он уже задумывается над вечными вопросами бытия, как и «русские мальчики» Достоевского. Его темы и образы живут в сознании читателей нового времени, возможно, уже на уровне генетической памяти культуры. 
Подводя итог работы секции, заметим, что хотя проблема рецепции произведений Ф.М. Достоевского не нова, однако мы до сей поры не имеем более или менее полной и систематизированной истории восприятия, то есть истории его читателей. Обсуждение этой актуальной темы, начатое на секции, решено было продолжить на следующих (восьмых) Летних чтениях в Даровом, которые пройдут в конце августа 2020 года.

\section{2. Усадьба Даровое в новом прочтении (по неизвестным документам)}

Так озаглавленная секция VII Летних чтений работала в режиме обновления источниковедческой базы, способной изменить наши представления об историческом контексте биографии и творчества писателя. Так, доклад Л.А. Воронкиной (Москва) и Т.Н. Дементьевой (Зарайск) «О смене владельцев сельца и деревни Даровое с 1829 по 1852 гг.» ввел в научный оборот новые документы по истории усадьбы Даровое, обнаруженные в Государственном архиве Тульской области (ГАТО) и Центральном государственном архиве г. Москвы (ЦГАМ). Это купчие на Даровое 1829 г., когда имение приобрела О.А. Глаголевская, и 1831 г. - времени начала владения Даровым семьей Достоевских, закладные документы на Даровое 1833 г., когда родители Ф.М. Достоевского приобретают деревню Черемошню, а также раздельный акт на имение 1852 г. между братьями и сестрами Достоевскими, согласно которому единоличной владелицей Дарового и Черемошни стала сестра писателя В.М. Иванова. Комплекс юридических документов позволил уточнить даты, связанные с ранней биографией Ф.М. Достоевского, территорию и объем землевладений его семьи, участников процесса приобретения имения в Каширском уезде Тульской губернии, его стоимость, в общих чертах - жилой и хозяйственный инвентарь. Данные документы позволяют внести существенные коррективы в сведения, содержащиеся в «Воспоминаниях» А.М. Достоевского, книге В.С. Нечаевой «В семье и усадьбе Достоевских», работе Г.А. Федорова «Московский мир Достоевского», в «Хронике рода Достоевских».

В докладе Т.Н. Дементьевой (Зарайск) и Э.С. Новиковой (Зарайск) «Размежевание земель сельца Дарового и деревни Даровой (по архивным документам)» рассматривался вопрос границ землевладений семьи Достоевских в имении Даровое. Чересполосно землями здесь 
владели помещики П.П. Хотяинцев, В.Д. Дашкова, И.А. Бартоломей, вольный хлебопашец Н.А. Фетисов. Датированные 1847-1850 гг., документы из фондов ЦГАМ подробно фиксируют процесс специального межевания, в результате которого наследники Михаила Андреевича и Марии Федоровны Достоевских стали единоличными владельцами земель сельца и деревни Даровое. Так, собственно, решился вопрос судебной тяжбы, начатой матерью писателя против моногаровского помещика П.П. Хотяинцева и подробно описанной как в семейной переписке, так и в «Воспоминаниях» Андрея Михайловича Достоевского.

Доклад И.А. Боголюбской (Зарайск) «Размежевание земель пустоши Старая Черемошня и деревни Черемошни» продолжил тему землевладений Достоевских в Даровом и окрестностях и посвящен был изучению ранее неизвестных документов из Центрального государственного архива г. Москвы (ЦГАМ). Это «Дело Каширского посредника 2-го участка о специальном размежевании дач и пустоши Старой Черемошни», «Дело о размежевании пустоши Старой Черемошни между помещиками М.А. и М.Ф. Достоевскими и П.А. Карепиным», и «Дело о специальном размежевании дач и деревни Черемошни коллежского асессора М.А. Достоевского, поручика В.Н. Ладыженского, майора П.П. Хотяинцева и священно-церковнослужителей села Моногарова» 1847-1858 гг. Земли Старой Черемошни являлись частью имения отца писателя М.А. Достоевского, которое после его смерти перешло сначала под опеку, а в 1840 году к «единственным и законным наследникам», то есть детям. В результате размежевания наследники - братья и сестры Достоевские - стали единоличными владельцами пахотной, луговой, лесной и усадебной земли пустоши Старая Черемошня общей площадью 54 десятины 912 квадратных саженей (до размежевания с соседями - помещиками П.П. Хотяинцевым и В.Д. Дашковой было 51 дес. 1797 кв. саж.). Межевание земель деревни Черемошни, принадлежавшей Достоевским, заняло 12 лет в силу того, что владельцев было несколько (помимо Достоевских, П.П. Хотяинцев, В.Н. Ладыженский, а также священно- и церковнослужители Свято-Духовского храма в с. Моногарове) и каждый отстаивал свои интересы.

Достоевские владели не только деревнями Даровое и Черемошня. В состав имения входил ряд пустошей, одна из которых Нечаевская, бывшая некогда селом с храмом Покрова Пресвятой 
Богородицы, откуда приход со временем переместился в Моногарово - в новую каменную церковь Сошествия Святого Духа. Доклад Д.А. Герасимовой (Зарайск) рассматривает дело специального межевания пустоши Нечаевой 1847-1858 гг. между владельцами П.П. Хотяинцевым, В.Д. Дашковой, наследниками умершего коллежского советника М.А. Достоевского - А.М. Достоевским, В.М. Карепиной, В.М. Ивановой. Размежевание длилось 11 лет ввиду того, что на земли претендовал и некий коллежский асессор Гоферланд, который, однако, не смог представить подтверждающие документы и потому не вошел в состав совладельцев. В результате размежевания П.П. Хотяинцев полностью вышел из состава владельцев пустоши Нечаевой, и с 1848 года в данной пустоши Достоевским принадлежало 60 десятин 239 кв. саж., остальными 208 десятинами владела В.Д. Дашкова.

В целом архивные документы Дарового и окрестностей по межевому ведомству 1840-1850-х гг. дают представление о землевладении Достоевских в преддверии крестьянской реформы 1861 г., чему посвящен был доклад А.С. Бессоновой (Коломна) «Выкупные дела Дарового и Черемошни». Выкупная кредитная операция была проведена в России при реализации крестьянской реформы 1861 г. и предусматривала предоставление крестьянам земли за выкуп. В Российском государственном историческом архиве (РГИА) хранятся выкупные дела Веры Михайловны Ивановой, сестры писателя, с 1852 года владелицы Дарового и Черемошни. Они представляют большой интерес с точки зрения характеристики экономической ситуации в двух деревнях в 18651867 гг., к которым относятся архивные документы. Крестьяне Достоевских после отмены крепостного права по-прежнему оставались на барщине, что и в новых условиях представлялось им более выгодным. Кроме того, из выкупных дел становится известно, что В.М. Иванова заложила Даровое и Черемошню в 1860 г. и с учетом долга за имением выкупная ссуда, получаемая помещицей, была невелика. Прилагаемые к делам Планы разверстания угодий и Уставная грамота наглядно показали границы господского и крестьянского владения, позволили уточнить местоположение усадебных построек, как жилых, так и хозяйственных. Эти сведения имеют особую ценность в виду предстоящей реконструкции усадьбы Даровое, определения охранных зон, музеефикации отдельных объектов. 
Большой интерес представляет лингвистическое исследование Дарового и мемориальных окрестностей, в частности, специфика топонимики «земли детства» Ф.М. Достоевского, который, как известно, включил в свои произведения ряд местных географических наименований.

В докладе «Топонимический ареал Дарового» А.С. Холодилина (Зарайск) рассмотрела историю возникновения и бытования ойконимов Даровое, Черемошня и Моногарово, их место в топонимической системе Растовского стана Каширского уезда конца XVI века. Источником для исследования послужили писцовые книги 1576 года, опубликованные в конце XIX века. Были охарактеризованы первые упоминания данных населенных пунктов в писцовых книгах, сведения об их владельцах, проанализирована структура описания, а также особенности моделей номинации.

В докладе А.Ю. Козловой (Коломна) «Топонимическая археология Дарового» были прослежены основные исторические события, повлиявшие на формирование топонимической системы Растовского стана Каширского уезда: принадлежность данной территории Рязанскому княжеству, первое упоминание Растовца в грамоте великого князя рязанского Олега Ивановича, относящейся примерно к 1372 (1371?) году; передача данной территории Солохмиру Мирославичу; в 1456-1462 гг. территория Растовского стана вошла в куплю московским князем рязанских земель. И с этого периода самой важной чертой топонимической системы Дарового и его окрестностей стала идея границы - именно здесь проходил рубеж между Зарайским и Каширским уездами, которые в разные периоды входили в состав разных губерний. Это прослеживается в особенностях топонимики изучаемой территории.

Доклад Л.И. Максимовой (Зарайск) «Из истории усадьбы Достоевских в Даровом» рассматривал дискуссионную проблему существования в бывшей усадьбе Достоевских музея в 1920-е годы, когда в Даровом жила племянница Ф.М. Достоевского Мария Александровна Иванова. В основе доклада - документы из Государственного архива Российской Федерации (ГАРФ), в соответствии с которыми докладчик считает, что формальных, юридических оснований для того, чтобы говорить о музее писателя в Даровом в первые годы советской власти, нет. Л.И. Максимова 
тем самым вступила в полемику с точкой зрения Г.С. Прохорова, утверждавшего на основании письменных источников, что существование музея в Даровом признавалось de facto целым рядом организаций и лиц, ратовавших за сохранение усадьбы [Прохоров, 2014]. Среди них и предшественник Л.И. Максимовой по зарайскому музею И.П. Перлов, писавший в 1925 году: «Чермашня и Даровое - это погибающий музей Ф.М. Достоевского; всеми брошенный и оставленный: домик разрушается, в усадьбе грязь и разоренье. Мы всегда плохо хранили память своих великих соотечественников; кажется, мы особенно небрежно относимся к памяти Достоевского» [Перлов, 1925, с. 527]. Начавшийся процесс музеефикации Дарового был тогда действительно насильственно прерван, однако он всё же способствовал приданию усадьбе неофициального статуса мемориального места, а Липовая роща вошла в список охраняемых объектов.

Доклады, прозвучавшие на секции «Усадьба Даровое в новом прочтении (по неизвестным документам)», показали, что ранняя биография Ф.М. Достоевского еще недостаточно изучена: важные для истории усадьбы Даровое документы по разным причинам оставались невыявленными, в силу чего отсутствовала целостная картина хозяйственно-экономической и юридической стороны жизни имения Достоевских. Интерес к судьбе русской деревни, вопрос о земле, столь остро поставленный в публицистике «Дневника писателя», имеют, несомненно, и даровские корни.

Кроме того, утраченные в советские годы усадебные постройки, произошедшая тогда же перепланировка деревни - всё это затрудняет наш путь к исторически достоверному представлению о «физиономии местности» такой, какой ее видел и помнил Ф.М. Достоевский. В свете предстоящего создания в Даровом полноценного музея, возникающих проблем музеефикации архивные документы приобретают первостепенное значение для более или менее аутентичной постановки нашего «зрения». Работа эта еще не завершена и предполагает дальнейшие поиски и расширение проблематики, что, в частности, было намечено в прозвучавших на секции лингвистических докладах. Изучение языкового и этнографического контекста, в котором проходило детство и отрочество Ф.М. Достоевского, представляет особый интерес с точки зрения влияния ранних впечатлений на творчество писателя. 


\section{3. Музей-усадьба Даровое: предложения к проекту Круглый стол 31 августа 2019 года. Даровое}

В обсуждении приняли участие:

Кирилл Вячеславович Кондратьев, директор Государственного музея-заповедника «Зарайский Кремль», чьим филиалом является усадьба Достоевских Даровое;

Владимир Николаевич Захаров, доктор филологических наук, профессор, почетный президент Международного общества Достоевского;

Альбина Станиславовна Бессонова, кандидат филологических наук, директор некоммерческого партнерства «Заповедное Даровое», руководитель временного научного коллектива по гранту РФФИ «Даровое Достоевского: документальные источники, биография, творчество» (в состав коллектива входят исследователи из Государственного социально-гуманитарного университета, г. Коломна, и Государственного музея-заповедника «Зарайский Кремль»);

Борис Николаевич Тихомиров, доктор филологических наук, заместитель директора Музея Достоевского в Санкт-Петербурге, президент Российского общества Достоевского;

Павел Евгенъевич Фокин, кандидат филологических наук, заведующий Музеем-квартирой Достоевского в Москве;

Любовь Александровна Воронкина, ландшафтный архитектор-реставратор, эксперт государственной историко-культурной экспертизы Министерства культуры РФ, член временного научного коллектива «Даровое Достоевского: документальные источники, биография, творчество»;

Владимир Александрович Викторович, доктор филологических наук, профессор Государственного социально-гуманитарного университета, председатель правления НП «Заповедное Даровое»;

Лидия Ивановна Максимова, главный хранитель Государственного музея-заповедника «Зарайский Кремль»;

Николай Николаевич Богданов, исследователь рода Достоевских;

Наталья Анатольевна Костина, старший научный сотрудник Дома-музея Достоевского в Старой Руссе.

К.В. Кондратьев. Чем ближе юбилей [200-летие Достоевского в 2021 г.], тем становится всё интереснее. Мы начинаем переходить 
от вопросов теоретических к вопросам практическим. Я вначале хочу вам передать привет и пожелания плодотворной работы от главы Зарайского городского округа Виктора Анатольевича Петрущенко. Мы вчера вечером подробно обсуждали с ним перспективы тех процессов, которые происходят у нас в Даровом. И можно сказать, что сейчас местное самоуправление выражает заинтересованность и готово оказывать полное содействие всем мероприятиям, работам, которые проходят в Даровом, и внимание это очень большое. В Московской области в соответствии с распоряжением губернатора Московской области Андрея Юрьевича Воробьева сформирован организационный комитет по подготовке к 200-летию Достоевского, в который входят руководители органов исполнительной власти, так или иначе задействованных в процессе создания инфраструктуры, обеспечения охраны памятников, связанных с Федором Михайловичем Достоевским. Одно заседание этого организационного комитета уже прошло.

Сейчас работы частично профинансированы либо запланированы бюджетные средства на работы в текущем году. Проводятся археологические раскопки. Сумма, выделенная из бюджета, - около 14 миллионов рублей, общая площадь, которая будет вскрыта, - около 3000 кв. м. Поставленную задачу, которую мы озвучивали в прошлом году, чтобы археологическими методами изучить территорию, на данный момент закрепленную за музеем, мы решаем в этом году. Следом за тем будет подготовлена научно-проектная документация на реставрацию флигеля и сохранение рощи как объекта культурного наследия - с дендроанализом, со всеми рекомендациями, которые должны быть даны по сохранению памятника живой природы. На следующий год мы получим смету по реставрации флигеля, и Министерство финансов Московской области подтверждает готовность выделить средства на реставрацию флигеля и на мероприятия по сохранению рощи.

По результатам прошедшего на прошлой неделе организационного комитета было принято решение о выделении музею дополнительных средств для разработки новых охранных зон, объединенной охранной зоны Дарового и Моногарова. Мы планируем провести конкурсные конкурентные процедуры в конце этого года, и в первой половине следующего года проект будет подготовлен. Я напоминаю, что в перечне основных мероприятий, утвержденном Правительством РФ, один из пунктов - это обеспечение охраны 
объектов культурного наследия и их музеефикация. Для нас это в первую очередь разработка охранных зон, то, что многие годы было камнем преткновения. Есть проект, разработанный много лет назад, он, к сожалению, не соответствует действующим требованиям законодательства к охранным зонам. И, так как сейчас по закону корректировать охранные зоны можно только путем разработки новых охранных зон, будут разработаны новые охранные зоны. И, может быть, это даже хорошо, потому что в тот проект нужно вносить много изменений, так как обнаружены новые документы, которые в нем не учтены, и у нас есть возможность, особенно благодаря архивным изысканиям последних лет, создать проект охранных зон с более глубокой научной проработкой и обеспечить охрану Дарового как объекта культурного наследия.

Также Министерством транспорта Московской области сейчас проводится проработка вопроса строительства дороги в обход Дарового, потому что это тоже проблема. Существующая дорога узкая, проходит через населенный пункт, и (мы об этом говорили на прошлогодних «Летних чтениях») это вызывает совершенно справедливое возмущение у местных жителей, потому что люди не всегда готовы к большому потоку приезжих. Поэтому планируется, что к музею будет восстановлен исторический подъезд и вход в комплекс со стороны въездной аллеи. И еще один важный инфраструктурный вопрос - это обеспечение коммуникаций, в частности, газификация. Есть примеры, когда отапливаются углем, мазутом и так далее, это проблемные вещи, поэтому в идеале мы сделаем доброе дело и для музея, и для моногаровского храма, и параллельно для жителей двух населенных пунктов [Дарового и Моногарова] - газифицируем их. Поэтому я надеюсь, что это как-то смягчит возможное недовольство местных жителей наличием здесь музея и оживлением жизни вокруг из-за большого потока туристов.

Еще один вопрос, который всегда тоже был проблемным, - это вопрос оформления земельного участка под музейный комплекс. В прошлом году я говорил о том, что сейчас наш музей не может официально тратить деньги на парк, проведение каких-то глобальных мероприятий и так далее по той причине, что большая часть усадьбы не находится в ведении музея. Большая часть усадьбы, в частности, та земля, на которой сейчас мы с вами находимся, территория парка, садов, Фединой рощи - всё это земля сельскохозяйственного назначения, которая входила в агропро- 
мышленный комплекс имени К.А. Мерецкова, принадлежавший Россельхозакадемии, и мы предполагали длительный процесс по переводу ее в собственность Московской области. Те, кто сталкивался с Росимуществом, знают, что это вопрос длительный и проблемный, но нам счастливый случай помог: распоряжение председателя правительства РФ о передаче всего комплекса АПК Мерецкова в Московскую область. В прошлом году эта территория была передана в областную собственность. И сейчас у нас уже завершается процесс с выделением территории, согласованы кадастровые схемы распоряжением Минимущества, в котором прописано, что земельный участок выделяется с целью передачи его музею для дальнейшей музеефикации, сохранения и т.д. То есть нам осталось только утвердить эту схему и получить официальное распоряжение Минимущества о передаче музею в пользование этого земельного участка. Это открывает перед нами возможность, уже не боясь нецелевого использования бюджетных средств, заниматься сохранением парка, сада и т.д.

Следующий этап - это пруд, потому что его тоже надо сохранять, надо проводить природоохранные мероприятия, нужно устанавливать береговую полосу, там работы на самом деле очень много, и первый этап будет опять-таки оформление. Но уже через Росимущество. Поэтому, когда дойдем до этого вопроса, мы, видимо, и Дирекцию [по координации подготовки и проведения празднования 200-летия со дня рождения Ф.М. Достоевского], и коллег будем привлекать к тому, чтобы этот вопрос активизировать.

Федора Михайловича, его творчество, биографию изучают много лет и продолжают находить что-то новое, что-то интересное. Вплотную занявшись подготовкой к реставрации усадьбы Даровое, мы поняли, насколько плохо мы представляем, а что же в ней было в тот период, когда здесь жил Ф.М. Достоевский. Вчера на конференции [«VII Летних чтениях в Даровом»] в ряде докладов мы слышали о том, что по многим вопросам работа еще не завершена, в архивах еще могут быть обнаружены дополнительные сведения. Тем не менее, те результаты, которые уже есть, позволяют нам значительно прояснить, что же здесь было в 30-е годы XIX века. Мы попросили Альбину Станиславовну Бессонову, руководителя временного научного коллектива, проинформировать о результатах последних архивных изысканий, о найденных новых документах, которые проливают свет на комплекс усадьбы Достоевских в Даровом. 
B.H. Захаров. Дорогие коллеги, мы вступаем в очень ответственный период. Времени до юбилея остается очень мало, впереди нужно сделать очень много. Успеем мы, не успеем? Должны успеть. Поэтому нужны прежде всего конкретные дела, инициатива. Я думаю, что сегодня во время круглого стола мы услышим много предложений, которые необходимо реализовать. В рамках исследовательской программы Российского фонда фундаментальных исследований принято 29 проектов, по которым ведется очень активная работа. Она уже приносит свои плоды, обогащая всех. Получается, что работает Альбина Станиславовна [Бессонова], а находит материалы для Павла Евгеньевича [Фокина], Борис Николаевич [Тихомиров] и Игорь Леонидович [Волгин] тоже находят материалы по грантам друг друга. Сейчас нужно как можно активнее и не теряя времени собрать то, что уже обнаружено, и составить план работы дальнейших архивных изысканий, чтобы не дублируя, оптимизируя свои усилия, собрать те материалы, которые необходимы для реставрации, музеефикации, научной экспозиции. Я лично после сегодняшнего осмотра археологических раскопок ничего не понимаю. Если у меня еще год назад были какие-то представления, я был уверен в том, где находилась усадьба, мазанка (найдем, не найдем - не так уж в конце концов и важно), предполагал, что основной акцент, наверное, можно сделать на виртуальной экспозиции, то после сегодняшнего осмотра мое сознание помутилось, я уже ничего не соображаю. Альбина Станиславовна, наверное, сейчас прояснит ситуацию.

А.С. Бессонова. На нашей секции [«Усадьба Даровое в новом прочтении (по неизвестным документам)» в рамках «VII Летних чтений в Даровом»], посвященной архивным изысканиям, мы говорили о наших находках первого года работы по гранту РФФИ. Сегодня я вкратце обозначу самые большие открытия 2019 года и скажу о перспективах нашей работы. Прежде всего, это, конечно, купчая на Даровое 1831 года, когда хозяевами усадьбы стали Достоевские. Этот юридический документ позволяет снять все вопросы относительно того, когда Достоевские приобрели Даровое. Здесь вплоть до момента совершения купчей крепости и введения во владение Марии Федоровны Достоевской [матери писателя] прописаны все даты. Указано точное количество крепостных душ, которых приобретали Достоевские. Снимается до сих пор бывший спорным вопрос относительно того, когда Достоевские всей семьей впервые приехали в усадьбу. Это было весной 1832 года. Данный факт влечет за собой 
некоторые корректировки в произведениях самого Ф.М. Достоевского, в частности, когда он в рассказе «Мужик Марей» вспоминает детство в Даровом и себя девятилетнего ${ }^{8}$. Документ позволяет прокомментировать и ряд имен собственных.

К сожалению, купчая крепость не перечисляет подробно жилые и хозяйственные постройки усадьбы Даровое - в первую очередь говорится о крестьянах, затем весь жилой, хозяйственный инвентарь, хлеб посеянный и ссыпанный в закрома и т.п. - всё, что приобретается на тот момент, всё переходит во владение Марии Федоровны Достоевской. Я считаю, что это очень большое открытие в рамках нашего архивного проекта, тем более что одновременно с этой купчей обнаружена и другая купчая - 1829 года эпизодической владелицы Дарового Ольги Алексеевны Глаголевской, которая тоже, пока по непонятным нам причинам, была владелицей Дарового буквально год с небольшим до Достоевских.

Еще один документ - это раздельный акт между братьями и сестрами Достоевскими 1852 года, по которому Вера Михайловна Достоевская [сестра писателя], в замужестве Иванова, стала единовластной хозяйкой усадьбы. Получается, с этого момента начинается в Даровом период Ивановых, продлившийся до 1929 года. Теперь эти документы, уже расшифрованные (сейчас мы работаем над их подробным комментированием) будут опубликованы. Я считаю, что это большой шаг в изучении истории усадьбы на мемориальный период.

Другое наше открытие архивное - это межевые документы полюбовного межевания 1847 года, в котором активно участвовали Достоевские вместе с другими владельцами смежных земель. Благодаря этим документам мы имеем самое раннее картографическое изображение Дарового по отношению к мемориальному периоду. На их основании мы узнаём, что Достоевские владели земельными наделами не только в Даровом и Черемошне: к их землевладениям относились, кроме пустоши Нечаевой, еще ряд пустошей и часть земель в Моногарове, потому что существует еще и полюбовное межевание в этом смежном с Даровым селе, где Достоевские также были заинтересованной стороной. Работа над этими документами, их расшифровкой и комментированием сейчас только начинается, потому что они оказались очень объемными по своему составу.

8 Первое лето в Даровом Ф.М. Достоевский провел в 1832 году, когда ему было 10 лет. 
Еще одна группа документов - это выкупные дела 1860-х годов, официальные границы этих дел 1866-1867 годы, однако сама процедура началась значительно раньше. Это ситуация, когда в пореформенном Даровом В.М. Иванова делилась с крестьянами земельными наделами. Смысл государственной выкупной операции в том, что временнообязанные крестьяне в определенный момент становились собственниками земли. И обнаруженные выкупные дела очень многое проясняют и в плане хозяйственного инвентаря, и расположения усадьбы, и прилегающих земельных наделов. О практической значимости того, что мы обнаружили, я сейчас скажу.

Самыми, на мой взгляд, информативными на сегодняшний момент для Дарового и грядущего проекта реконструкции усадьбы являются, конечно же, межевые дела и те планы, которые были ранее известны и уже частично опубликованы, а также те планы, которые мы обнаружили. Сейчас мы имеем такую даровскую иконографию в движении времени, которая, как мне кажется, позволит все-таки примирить коня и трепетную лань, я имею в виду архивные документы и археологические раскопки. Пока у меня такое ощущение, что мы идем параллельно, мы не пересекаемся, не взаимодействуем, хотя первую попытку я сделала, когда в этом году Александру Сергеевичу Сыроватко [руководителю археологических исследований], еще только приступавшему к работе, отправила геодезическое описание Дарового из выкупного дела, в надежде, что это в какой-то степени его сориентирует и поможет в археологических раскопках.

Перед вами план сельца Дарового генерального межевания 1770 года. Это документ, относящийся к периоду, когда хозяевами сельца Дарового и деревни Даровой были помещики Хотяинцевы. Когда мы смотрим на эти изображения в движении времени, мы видим, как менялась усадьба, что в ней появлялось или исчезало, и в какой-то степени это для нас подсказки относительно работы археологов, и относительно проекта.

Вот на плане 1770 года речка Уйна, которая соединяет две деревни, Даровое и Моногарово. Верховья этой речки здесь, в овраге под названием Лоск. Далее Липовая роща с садами (видимо, топографы объединили этот зеленый массив), жилая и хозяйственная часть усадьбы. Карты составлялись по определенным канонам: коричневым изображаются постройки, а зеленым - прилегающие к ним жилые, обихоженные территории, мы это сейчас увидим и на планах деревенских. Все точки координат есть, и я говорила с Александром 
Сергеевичем [Сыроватко] относительно того, что существуют современные компьютерные программы, которые позволяют геодезию старую, историческую соединить с современной и добиться этого наложения. Да, хотя там и ориентировались по магнитной стрелке, свои были рубежи и румбы, специфическая привязка к местности, но, тем не менее, есть какие-то точки соприкосновения, с которыми мы можем работать. Кстати, хочу показать пояснение обозначений на этом плане: вот само сельцо выделено и нарисована очень интересная вещь - столбы и ямы. У меня вопрос к археологам: а не поискать ли нам (они здесь в окрестностях Дарового были) межевые ямы (столбы мы, естественно, уже не обнаружим), потому что для них были свои замечательные ориентиры (и они прописаны во всех планах): в ямы насыпались угли как материал не гниющий и отмечающий рубеж.

А вот общий вид геометрического специального плана сельца Дарового 1847 года, когда происходило полюбовное межевание между наследниками Марии Федоровны и Михаила Андреевича и их соседями. Участников здесь много, иногда доходило до 10 человек, потому что положение пограничное: здесь вклинивается и Рязанская губерния, в частности, сельцо Шистово, в которое переходит Моногарово. В данном случае это самый ближний к мемориальным 1830-м годам план сельца Дарового - так, как оно выглядело до всех преобразований В.М. Ивановой. Помните предыдущую картинку? Что изменилось? Водное зеркало появилось, но всё равно называется речка Уйна. Она уже запружена и превращена в пруд, тот самый, который мы сейчас называем Маменькин. Далее зеленый массив, сад. Что здесь интересно - постройки. Видите, как поменялась физиономия местности? Моя гипотеза: это условное изображение - господский дом, а это - одна из хозяйственных построек. Какая, пока не могу сказать, а вот это - улица села, здесь живут крестьяне, так на этом плане показан ряд крестьянских домов.

Еще одно изображение - военно-топографическая карта 1854 года. Военные - люди точные, и они подобные карты составляли предельно подробно и основательно. Здесь мы видим село Моногарово, сельцо Даровое и деревню Черемошню. Чем интересна данная карта в плане физиономии местности? На повороте в Черемошню, на дороге из Венева в Зарайск, постоялый двор на одной стороне этой дороги и на противоположной стороне кабак. Дополню, что на этом самом повороте, когда Достоевские сворачивали с большой дороги на 
Даровое, стояла еще деревянная часовня. Кабак, часовня, постоялый двор - всё очень по-достоевски. Если мы посмотрим на эту карту, что мы увидим? На всех таких картах сплошными линиями изображаются деревенские улицы, включающие дома крестьян, которые никак не конкретизировались. Это уже усадебная земля крестьянская (она тоже называлась усадебной) - черта оседлости даровских крестьян. И абсолютно такая же линия на противоположной стороне улицы. А что видим в господской усадьбе? Построек крайне мало.

Еще один, самый поздний по времени план, из Тульского государственного архива. Это часть межевых дел. Странная архивная ситуация: сами документы хранятся в Петербурге в Историческом архиве [РГИА], где я с ними работала, а вот планов межевания, самого главного, в них нет - они, как оказалось, хранятся в архиве Тулы. Это планы тех земель, которые по выкупной операции В.М. Иванова передавала своим крепостным крестьянам Дарового и Черемошни. Общий план создавался на Даровое и Черемошню. Напоминаю, что по выкупной операции помещица делилась с крестьянами не только полевыми наделами (что и составляло главную цель выкупа), но и усадебными наделами - то есть той территорией, на которой исконно крестьяне проживают. Мы видим участок Дарового, который переходил по выкупным делам крестьянам. Крестьяне получали также часть земли на «господской» стороне Дарового: начиная от нынешнего дома № 1 вся нечётная сторона улицы вплоть до берега пруда. Значит, это тоже была черта крестьянской оседлости, крестьянские усадьбы, по выкупным делам отходившие крестьянам.

Выкупные и межевые документы подсказывают, где какие постройки располагались, потому что и постройки, и отдельно стоящие деревья, и межевые ямы, и поля со своими названиями являются ориентирами, как двигаться, как проводить рубеж, как размежеваться с соседями и крестьянами. Здесь мы видим интересный участок, сиреневым цветом нарисованный, с надписью «прогон». Это прогон для коров, который ведет на ту луговину, которая до сих пор сохранилась в Лоске, это часть Дарового, знаменитая по «Мужику Марею». Здесь находятся хозяйственные постройки Веры Михайловны Ивановой: овин, рига, сарай, гумно. Поименовано всё отдельно, всё это не является синонимами по отношению друг к другу - это четыре разных, но взаимосвязанных объекта, комплекс по переработке зерна. Таким образом, ряд хозяйственных построек проясняется по этому плану. Более обтекаемо в проекте разверстания угодий говорится о жилых 
постройках помещицы, но наводка определенная есть: когда крестьяне требовали отрезать им побольше земли и говорили о том, что хотят границу разверстания продолжить вплотную к господскому дому, просят луговину недалеко от него (я так полагаю, это то место, где стоит сейчас памятник) и поле, которое соединяет Даровое и Нечаевский погост. Претензии крестьян мировой посредник отклонил. Но так или иначе речь о господском доме идет. Почему я на этом сосредотачиваю внимание? Это 1860-е годы, Вера Михайловна еще никакими перестройками в родительском имении не занималась, всё это начнется в 80-е годы. Требуемая по документам граница между помещичьим и крестьянским наделом в непосредственной близости от господского дома должна подсказать его местоположение (наиболее спорный до сих пор вопрос) - именно там, где сейчас находится флигель.

Сейчас многие археологические находки еще требуют датировки. И я все-таки надеюсь, что археологические работы объединятся с нашими архивными открытиями, что археологи посмотрят на эти планы профессиональным взглядом с учетом всех геодезических описаний и точек координат и прилагающихся к ним пояснений, которые очень многое могут подсказать.

Что отходило крестьянам по разделу в Черемошне? Получается, что всё. Перед нами деревня Черемошня такая, какой она показана на всех планах межевания - и генерального 1770 года, и специального, и плана выкупного дела. Вера Михайловна идет на некоторые уступки и крестьянам, кроме территории их усадебной оседлости, отдает свой фруктовый сад, судя по проекту разверстания. У меня есть предположение, что в Черемошне, хотя это и деревня, какие-то господские строения должны были существовать9. Потому что по всем исповедным ведомостям [1830-1840-х гг.] в Черемошне значится двор дворовых людей. Зачем дворня в деревне, где нет господского дома? Чем они там занимались? Если даже и не было господского жилого дома, по-видимому, обихаживали сад.

Земельные наделы, которые мы видим на планах межевания и особенно в выкупном деле, поясняют, как делать проект охранных зон. Думается, в данном случае надо исходить из того, где заканчивались владения Достоевских. А они простирались вплоть до

9 А.М. Достоевский в своих «Воспоминаниях» говорит о бане, которую семья посещала каждую неделю. В письмах к мужу М.Ф. Достоевская упоминает птичник, скотный двор, сад. Всё это, конечно же, господское хозяйство в Черемошне. 
деревни Алферьево, алферьевский мост - это один из ориентиров, где проходил рубеж между землями Достоевских и помещиков Алферьева. По выкупному делу мы теперь знаем, что земля под дорогой [Зарайск - Серебряные Пруды] принадлежала Достоевским, и территория за дорогой до речки Грустынки также должна войти в охранную зону. Подобным образом следует поступить и с мемориальной территорией Черемошни и Моногарова.

Б.Н. Тихомиров. Как мы помним, в «Братьях Карамазовых» не деревня Черемошня, там роща Черемошня. Вы показывали последний план, фруктовый сад там указали. Для рощи есть какие-то основания?

А.С. Бессонова. Это вопрос топонимии. Брыково, всем хорошо известное по роману «Бесы», начиналось здесь, в Даровом, в этом самом овраге, который сейчас называется Федина роща (в XX веке он превратился из березняка в осинник). И по всем планам Брыкова роща доходит до Черемошни (это полтора километра), где имеет название Черемошнинский верх. Есть предположение, что березовая роща черемошнинская - тот самый Черемошнинский верх, который присутствует на планах.

Б.Н. Тихомиров. Второй вопрос по купчей. Кирилл Вячеславович [Кондратьев] отмечал, как плохо до последнего времени было изучено всё, что связано с Даровым. Лишнее свидетельство, скажем: в «Летописи жизни и творчества Ф.М. Достоевского» в первом томе под 1831 годом черным по белому написано, что вообще Достоевские купили Даровое у Хотяинцевых. Хотя о Глаголевской Нечаева вспоминает еще в книжке 1939 года. Вы нашли купчую Достоевских у Глаголевской, которая датируется...

А.С. Бессонова. ...1831 годом. Я не одна, нас 10 человек работает, я просто обобщаю работу. Все вопросы относительно состава купчей вы можете задать участнику нашего проекта Любови Александровне [Воронкиной].

Б.Н. Тихомиров. Но вы сказали: Достоевские приехали впервые в Даровое в 1832 году.

А.С. Бессонова. Да, потому что купчая датируется 7 августа 1831 года, а введение Достоевских во владение состоялось в 1832 году.

Б.Н. Тихомиров. Вот. Потому что для нас более важный вопрос: не когда Достоевские, а когда дети Достоевских здесь впервые появились. 
А.С. Бессонова. В 1832 году.

Б.Н. Тихомиров. Тогда они приехали уже на погорелье?

А.С. Бессонова. Да.

Б.Н. Тихомиров. Но по воспоминаниям Андрея Михайловича нет впечатления, что первый вид Дарового - это сгоревшее Даровое.

A.С. Бессонова. Нет-нет, там есть такое, надо просто повнимательнее почитать.

Б.Н. Тихомиров. Читал!

A.C. Бессонова. Я не в упрек! Я тоже много Достоевского читала, но сейчас, работая с новыми документами, делаешь такие неожиданные открытия для самого себя: думаешь, что это было вот так, а документ говорит: нет, это было совсем по-другому.

Б.Н. Тихомиров. Еще вопрос в этой связи: ведь Достоевские собирались купить у Глаголевской еще одно имение, если я не путаю, Крапивна, вносили залог, потом из-за того, что был пожар и они разорились, они не могли выплатить остальную часть и этот залог был потерян. Вот документов на второе имение нет?

А.С. Бессонова. Нет. А у вас откуда такие сведения, что они у Глаголевской собирались еще что-то купить?

Б.Н. Тихомиров. Надо посмотреть, сейчас не вспомню, но я думаю, что от Нечаевой ${ }^{10}$.

А.С. Бессонова. Вам будет интересно, что проясняют эти небольшие по своему объему документы - купчие. Так, мы знаем благодаря Андрею Михайловичу [Достоевскому], что Хотяинцевы, которые были в судебной тяжбе с Достоевскими из-за чресполосного владения, хотели держать Достоевских «в тисках». Одновременно с Даровым продавалась и Черемошня, а Хотяинцевы это утаили от Достоевских. У нас же теперь есть закладные документы - это тоже одно из наших открытий - когда Мария Федоровна закладывает Даровое, чтобы купить Черемошню. Обнаружены и закладные документы на саму Черемошню, потому что заемную сумму за Даровое надо было вернуть через год. По документам кредитором Достоевских выступает А.А. Куманин. До этого было известно лишь, что они «заняли у родственников». Вот

10 Сведения о том, что Достоевские собирались приобрести у О.А. Глаголевской имение Косая Губа в Крапивенском уезде Тульской губернии, содержатся в книге: [Федоров, 2004, с. 174-176]. Однако этот факт никак не подтвержден точной ссылкой на архивный источник и требует проверки. 
так мы многие вещи можем прояснить в связи с историей Дарового и ранней биографией Федора Михайловича.

Н.Н. Богданов. Если возвращаться к воспоминаниям Андрея Михайловича [Достоевского], то у меня осталось впечатление, что он описывает пожарище, но при этом он видел усадьбу до пожара, что сейчас никак не получается. Потому что он пишет, что курганы остановили огонь. Может быть, он по рассказам это знал и включил. Вообще у Андрея Михайловича чудовищное количество ошибок, это надо иметь в виду.

А.С. Бессонова. У него, например, есть такое признание: «Все воспоминания свои о деревне <..> я не могу подразделить, какие <события> из них случились в какой год» [Воспоминания..., 1930, с. 76-77]. О чем-то осталось только общее впечатление. Он маленький еще ребенок был! Мы его хвалим за подробные воспоминания: архитектор в нем сразу виден - всё описано дотошно. Но дело в том, что эти детские вспоминания как вспышки, это лишь отдельные эпизоды. Они собраны в общую картину, но это не значит, что Андрей Михайлович каждый день и каждый год фиксировал подробно, неизбежно могли быть какие-то хронологические смещения.

Н.Н. Богданов. Иначе и не могло быть, потому что в памяти всё смещается. Но у памяти Андрея Михайловича больший недостаток: когда ему казалось, что он абсолютно твердо уверен, что это было именно тогда, а оказывается...

А.С. Бессонова. К вопросу о пожаре. Вернемся к самому раннему плану [1847 года], для нас ценному. Вот граница, которая отделяет собственно сельцо от господской части. Мы видим, что все строения в одну линию поставлены вдоль улицы. Такого не было, например, при генеральном межевании у Хотяинцевых - там все постройки стоят в форме каре. Поэтому если и искать следы пожара, то, наверное, ближе к красной линии.

К.В. Кондратьев. Не могло так прогореть: 10 метров, а дальше следов пожара нет. У меня был один комментарий к плану XVIII века, где показана усадьба Хотяинцевых. Там пунктиром обозначены не только межевые рвы, но и поля координат, поэтому очень важно не запутаться и в каких-то углах не увидеть межевой ров.

Л.А. Воронкина. В указанном месте это ограда.

К.В. Кондратьев. Да, где-то ограда, это видно. Можно еще раз вернуться к плану 1847 года? Спасибо. Мы-то всё о том, что тут 
было, как это выглядело, и какой имущественный комплекс видел здесь Федор Михайлович, а у этого плана есть ведь вторая половина - деревня Даровое.

Л.А. Воронкина. Она вот с этой (западной) стороны от сельца Даровое.

К.В. Кондратьев. Я делал наложение на современную карту (причем одним из таких наложений мы нашли зарайский острог в этом году, археологически подтвердившийся с точностью чуть не до метра). И я делал наложение обоих планов на местность. Дорога наша кривая по Даровому ложится совершенно точно, очень хорошо ложатся очертания пруда. То есть план на самом деле очень точен. Но, если посмотреть на вторую половину, на деревню Даровую, там крестьянские дворы обозначены отдельно, «поштучно». Здесь мы видим большую длинную постройку. Если мы посмотрим еще раз на вторую половину плана, то за рекой (плотина, и дальше река продолжается) и выше реки есть еще две большие постройки, которые явно не являются крестьянскими домами. Мы помним о том, что это барщинное имение. В сущности, это колхоз. Там должны быть общие большие постройки с барским скотом. Понятно, что есть какая-то хозяйственная деятельность, которая доставляет неудобство владельцам, пахнет, например, нехорошо. Здесь, возможно, скотный двор, какие-то амбары... Это некий хозяйственный комплекс с прилегающей территорией. Там же могли жить и дворовые. В этом отношении очень интересно: по выкупным делам как-то прописывается, где дворы просто крестьян, где дворы дворовых?

А.С. Бессонова. Нет, такого нет.

К.В. Кондратьев. Тогда стоит вопрос: если всё, что с нашей стороны дороги - усадьба помещика, это не исключает, что здесь живут крестьяне, потому что должны быть дворовые. Владельцы приезжают и уезжают, а они живут здесь постоянно, в любом случае кто-то должен жить здесь регулярно. И с какого-то момента мы видим здесь какую-то нарезку, и местные жители говорят: мы испокон века живем здесь, на этой (усадебной) территории. Вот где этот «испокон»? С какого века они живут именно на этой территории? Либо это наследие того, что там были дворовые, либо это старый скотный двор... Я не хочу сейчас поставить точку, мы продолжаем искать. И это головная боль безумная, потому что при перспективах музеефикации и т.д. мы не можем здесь промахнуться, мы должны знать однозначно и наверняка. 
Я хотел сказать еще по поводу охранных зон. Ведь есть зона охраны, зона регулируемой застройки и территория памятника. Это разные вещи.

А.С. Бессонова. И зона охраняемого ландшафта.

К.В. Кондратьев. Да. Если мы сейчас в территорию памятника весь имущественный комплекс Достоевских включим, меня точно распнут где-нибудь тут между липами. И ни один эксперт под это не подпишется - это нереально. Ландшафт у нас еще на старом плане, он у нас охраняется практически в границах этого документа. Это просто комментарий к слову. Я не говорю, что надо смягчать режимы, но и в территорию памятника мы всё включить не сможем. У археологов, кстати, эти планы есть и наложение это есть, поэтому следующий этап раскопок распланирован именно с целью выловить эти постройки, которые на плане обозначены, но, к сожалению, в соседский огород влезть не можем, они не пускают.

А.С. Бессонова. А район въездной аллеи, там, где гумно могло быть?..

К.В. Кондратьев. Там не территория музея. Возвращаемся к нецелевому использованию бюджетных средств. Как только это будет территория музея, я подпишусь подо всем, пока же мы не имеем права там копать. Мы можем тратить деньги, только если земля закреплена за нами. Бюджетный кодекс, извините.

В.Н. Захаров. А передать деньги «Заповедному Даровому», чтобы они распорядились?

К. В. Кондратьев. Бюджетная система не предусматривает такого субсидирования, только в качестве гранта, а это отдельная статья. А потом и «Заповедное Даровое» не может не на своей земле копать. Гранты, да, пока земля в собственности Московской области, мы постараемся взять себе и исследовать... Здесь следует понимать, что 2021 год действительно не за горами, что-то мы точно успеваем, что-то мы должны успеть и понимаем, что у нас не всё складывается. Но это же не значит, что в 2021 году мы поставили точку и сказали, что мы сделали вот это и больше ничего делать не будем. У нас есть примеры, когда застолбили некую территорию, а следующим этапом, когда земля будет оформлена, мы проведем там раскопки и установим следующий небольшой комплекс. Это уже вопрос этапности действий. У нас проблема в другом - в сроках. То, что мы сейчас делаем, нужно делать «с чувством, с толком, с расстановкой» три-четыре года: хорошо отработать архивы, всё это сочленить, 
покопать, оформить... Но нам «не повезло»: Федор Михайлович родился в 1821 году, он нам не дал этого срока.

Возвращаясь к нашим делам, есть еще тема для рассмотрения. Планы бывают точны, бывают и не очень. Вот опять проблема: с одной стороны, пожар нас «спасает», потому что мы точно знаем, что они приехали на чистый лист - всё, что было при Хотяинцевых, сгорело. Дальше мы начинаем говорить, как это всё складывалось, какая была застройка...

Л.А. Воронкина. От пожара спаслась мазанка...

К.В. Кондратьев. Мазанка да, была и очень хочется ее найти. Мы уже разговаривали, и есть большое подозрение, что мазанка под домом, под флигелем.

Л.А. Воронкина. По воспоминаниям Андрея Михайловича, мать сестру Сашеньку рожала во флигеле, а дети в это время ждали в мазанке (25 июля 1835 года). Так что эта версия однозначно отпадает.

К.В. Кондратьев. Если дендроанализ нам не скажет, что флигель 1870-х годов. К концу года мы точку поставим в этом, я думаю. Заодно и копнем.

В.А. Викторович. Это тоже не окончательно: дом мог перестраиваться на том же самом фундаменте...

К.В. Кондратьев. Мы соберем всё вместе - и письма по поводу того, что разобрали, переехали и т.д. и т.п., всё это сочленим и будет какая-то история. Вдобавок дополнительно покопаем и, может быть, найдем еще какой-нибудь фундамент. Что касается утверждения А.М. Достоевского, якобы между двумя курганами стояла мазанка. Перечитаем А.М.: вблизи двух курганов стояла мазанка ${ }^{11}$. Вблизи и между - вещи разные. И кроме того, А.М. нигде не пишет, сколько курганов вообще в усадьбе. Их могло быть три, четыре. Они могли оплыть, потому что курганы, которые мы видим сейчас, забиты советским мусором, советским кирпичом. То есть их подсыпали. Поддерживали. Эти два сделали, а другие могли не сделать. Поэтому здесь нужно еще раз внимательно посмотреть и именно в сочетании с планами.

В.Н. Захаров. Можно к вопросу о пожаре? Я думаю, что тот пожар, который был, это все-таки исторический факт, который подтвержден очень многими свидетельствами. Вряд ли восстанавливали на пожарище дома, строили новые, не убрав основательно следы по-

11 Давайте перечитаем: «Плетневая наша мазанка, окруженная двумя курганами, была защищена вековыми липами и не сгорела» [Воспоминания..., 1930, с. 61]. 
жара. Могли очень хорошо расчистить и поставить эти новые дома. Допустим, один дом, в котором гирьку нашли и прочий инвентарь того времени, это дом старосты... При скотном дворе скотник жил, конюх, еще кто-то... Эта сторона имения [от барского дома до пруда] могла быть заселена дворовыми людьми, а крестьянские усадьбы по другую сторону дороги. Наверное, все-таки хорошо расчистили, раз следов пожара нет, и строили новые дома, маменька по 50 рублей каждому погорельцу выделила, и деревня заново отстроилась. Мне кажется, что мы потому не видим следы пожара, что хорошо убрали.

К.В. Кондратьев. У нас был опыт на территории Зарайского кремля очень интересный: сделали шурф не у стены, как мы сейчас копаем в рамках охранных раскопок, а чуть в глубину территории. И очень хорошо читалась стратиграфия, там хорошо был показан и XIX век, она очень хорошо нам показала и период строительства кремля, тесаный известняк, мерзлотные процессы и т.д. У нас там была очень тонкая, едва заметная линза пахоты начала XIII века. И нам очень повезло, что приехала в прошлом году международная группа почвоведов, и сейчас мы совместно готовим публикацию большого материала, посвященного почвоведческому изучению этого культурного слоя. В частности, там у каждого вида этой почвы был взят анализ на химсостав и т.д. И вот эта тонкая-тонкая, буквально полсантиметра линза пахоты начала XIII века четко фиксируется по остаткам фтора. Фтор остается после навоза. Причем почвоведы говорят: не вымывается, фтор остается навечно, если там никто не перепахал заново. Эта линза очень четко фиксируется. И сейчас на территории Зарайска во время раскопок мы видим два пожара. Понятно, что пожар в городе и пожар в усадьбе - это разные вещи. Но каждому студенту исторического факультета на первом курсе, на занятиях по археологии рассказывают о том, что не занимались они таким изуверством, не издевались над самими собой - наши предки никогда не чистили до конца, и благодаря этому есть культурный слой. Вот в чем дело. Всё равно остаются следы пожара, которые втоптались животными, людьми. То есть следы пожара, если он был, должны были хотя бы тонкой линзой остаться и быть видны в стратиграфии. Вот почему нужно копать. Когда по Зарайску работал георадар, он не показал ничего там, где огромный четырехметровый острожный ров. Это можно только руками пощупать. И мы сейчас с вами увидели: да, есть ямы с пеплом, они фиксируются. Здесь углистость некоторая присутствует, 
то есть мы понимаем, что здесь действительно что-то горело, мы видим выбросы печные, но линза пожара... Я не оправдываю то, что ее нет, тем, что не было пожара. Но это - загадка. Может быть, мы эту линзу плохо видим, и она осталась действительно в этих ямах, куда убирались все остатки, и она была очень тонкая, и всё перемешалось там, либо мы, как я сказал, где-то на периферии. Поэтому то крупное, что действительно горело, мы найдем.

А.С. Бессонова. Ну как, Кирилл Вячеславович, может быть периферия: вы накладываете планы, всё совпадает...

К.В. Кондратьев. Мы накладываем планы, всё совпадает, хотяинцевская усадьба должна стоять здесь, но ни одного фундамента нет, а фундаментные камни есть в яме. С линзой горелого материала. Археологи работают с конкретным живым материалом. Они видят какую-то яму, какую-то углистость там и т.д., и они могут предоставить разные варианты. Если их спросить: а это мог быть какой-то сбор, смёт пожара? Археолог скажет: да, могло быть, а могла быть и яма для отжога мусора, а могло быть и еще что-то такое. Но для этого и вы с документами и архивами, чтобы показать, что нам больше всего подходит смёт пожара.

П.Е. Фокин. У меня вопрос не к раскопкам. Есть еще один источник, который всё время вводится некоторыми исследователями. Я имею в виду фотографии, которые хранятся в нашем музее. Я понимаю, что они позднего времени, но какого времени и что там изображено? Какая-то работа идет сейчас в этом плане?

А.С. Бессонова. Мы надеемся. Вчера у нас был круглый стол по архивным документам, и мы определяли перспективы следующего года работы. В архивах мы продолжаем работать, но теперь в круг нашего внимания включаются и музеи. У вас я уже побывала, метрические книги посмотрела. Фотографии я еще смотрела с Татьяной Юрьевной Соболь [сотрудником Гослитмузея], она мне показывала...

П.Е. Фокин. У нас есть какие-то планы (копии) Дарового...

А.С. Бессонова. Да, все изоматериалы, какие есть, она мне в свое время показывала, что-то мы даже для своей выставки зарайской копировали. И некоторые вещи, конечно, очень интересные, они требуют комментариев...

П.Е. Фокин. Интерпретации.

А.С. Бессонова. Да.

П.Е. Фокин. То, что один вариант интерпретации есть [Т.Г. Бирюковой], мы знаем, но он своеобразный... 
А.С. Бессонова. Да. Поэтому мы работаем с этим вопросом. И к разговору об источниках происхождения архивных документов: есть одно совершенно замечательное карандашное изображение флигеля - таким, каким мы его не застали, до ремонта 1990-х годов. Очень красивое изображение.

П.Е. Фокин. Где?

А.С. Бессонова. В Гослитмузее. И когда я Татьяну Юрьевну [Соболь] спросила об источнике поступления, она ответила: не знаю! Про это изображение никакой информации нет. Мы его копировали, на выставке [в Зарайском благочинии] оно есть.

Б.Н. Тихомиров. Павел Евгеньевич, тут к вам как раз очень серьезное предложение. Эти фотографии очень невнятные, я с ними знакомился у Татьяны Юрьевны, они очень невнятно описаны и их происхождение. И от кого поступили.

П.Е. Фокин. Поступили они от Александра Львовича Хмырова [внука Софьи Александровны Хмыровой-Ивановой, племянницы Ф. М. Достоевского].

Б.Н. Тихомиров. На обороте «Даровое» со знаком вопроса, который часто в публикациях пропадает. Потом время создания. У меня вопрос был, насколько вообще в 80-е годы XIX века возможны такие фотографии вдали от столичных центров на пленэре.

Н.Н. Богданов. Это 1900-е годы, снимал Лев Дмитриевич Хмыров [сын С.А. Хмыровой-Ивановой] 1878 года рождения.

Б.Н. Тихомиров. То есть вам тоже нужно свою работу довершить, чтобы мы уже получали от вас твердые данные.

П.Е. Фокин. Вся проблема заключается как раз в том... у нас был с фондовиками разговор, что в госкаталог они должны вписать то, что вписано в книгу поступлений. И понимаете, как бы ни бились, если записано: Даровое, то и будет идти как Даровое в каталоге. Но может быть что угодно.

Л.И. Максимова. У нас есть негативы 1924 года, кажется. Они подписаны, кто фотограф. И, скорее всего, эти негативы были сделаны по заказу Наркомата просвещения, музейного отдела, когда за Даровым наблюдал Зарайский музей. Мы сделали их отпечатки

П.Е. Фокин. У нас фотографии любительские и действительно начала XX века, конечно, не XIX века, когда любительская фотография настолько не была развита.

В.А. Викторович. Лидия Ивановна, а вот эти негативы совпадают с известными нам фотографиями, или есть что-то такое, что нам неизвестно? 
Л.И. Максимова. Есть опубликованные - там, где они [М.А. Иванова с гостями] сидят вместе на террасе, и есть несколько фотографий рощи, в роще какие-то строения... Мне кажется, они уже достаточно известны. Надо, конечно, тоже сесть и сравнить.

Н.Н. Богданов. Нет, но вот те фотографии, о которых шла речь, переданные в Гослитмузей Александром Львовичем Хмыровым. Прежде всего они действительно очень невнятные. Я могу ошибиться, но они переданы уже на моей памяти, мне казалось, что это были уже 2000-е годы.

П.Е. Фокин. Там есть вещи, которые на номерах...

Н.Н. Богданов. Он отдал всё Галине Борисовне [Пономаревой, тогда заведующей московским музеем Достоевского], а она потом что-то передала, а что-то не передала. Фотографии чрезвычайно невнятные, они любительские, плохого качества, и они такого бытового плана, что по ним трудно сориентироваться. Там сфотографированы люди, которые сидят возле каких-то построек. Там дети Софьи Александровны и Дмитрия Николаевича Хмыровых. Скорее всего, это снято действительно в Даровом. Фотографии поражают тем, что там большое количество построек каких-то, в которых очень трудно сориентироваться, и они не привязываются ни к чему. При этом Александр Львович отдал эти фотографии в музей только потому, что он не понимает, кто и что на них изображено. Хотя там его отец.

Л.А. Воронкина. С 2005 года по приглашению Владимира Александровича [Викторовича] мы (РБОО Центр традиционной русской культуры «Преображенское», затем ООО «Парковая реставрация», г. Москва) занимались Липовой рощей, занимались архивной работой, получается, уже 14 лет. С интервалами временными, потому что здесь работали и другие исследователи, помогали Владимиру Александровичу. Я хотела бы поблагодарить всех, кто здесь ухаживает за парком. В 2005 году здесь была крапива по пояс, все дубы в мучнистой росе. Сейчас крапива скошена, кое-где образовались травяные дорожки, дубы пролечены, подсажены липки. Это положительные моменты. Восстанавливается сад - тоже замечательно. Единственный минус: как я поняла, сорта яблонь подбирались те, которые были на момент посадки без учета исторического ассортимента. Поскольку мы имеем объект культурного наследия, такой объект предусматривает восстановление растений в том ассортименте, который был на мемориальное время. И посадка американской се- 
лекции яблонь, конечно, неуместна. Со временем их надо заменить. Ассортимент мы можем подсказать.

По Липовой роще. Мой опыт реставратора (23 года я занимаюсь историческими парками), показывает, что наша Липовая роща имеет естественное происхождение. К сожалению, со временем изводились крестьянами эти леса, они почти не сохранились. Заготавливалось лыко с молодых липочек, которые как раз и давали возобновление естественное. Заготовлялось совершенно бесконтрольно: по миллиону лаптей Россия выпускала в год, плелись лыковые кули - это упаковочный материал, который был самым обычным. И всё это, конечно, сводило молодую липу к нулю. И наше счастье, что Липовая роща (ее можно даже назвать реликтовой) сохранилась.

Существует мнение, что роща создавалась изначально как регулярный сад. С этим нельзя согласиться. То, что происхождение рощи естественное, показывает расположение лип - хаотичное, нет ни единого намека на ряды. Если прочитать воспоминания Андрея Михайловича [Достоевского], он говорит, что липовая столетняя роща. Значит, от 1830-х отнимаем 100 - получаются 1730-е примерно. И причем он называет ее рощей. Если бы это был бы сад, он бы говорил «липовый сад», от слова «садить», а роща - она сама вы-рос-ла.

Могут возразить, что присутствует так называемая букетная посадка, которая применялась в садово-парковом искусстве как акцент, как композиционный элемент, чтобы сделать дерево букетом, чтобы смотреть со всех сторон. Но наши липы сидят по многу штук из одного корня потому, что как только дерево выпадало, то корневая поросль образовывала тот самый букет. Много лип по две штуки, потому что липовая семянка содержит по два орешка: семянка упала - выросли две липки. И планировочная структура липовой рощи - не строго правильный прямоугольник, мы это видим на плане сельца Дарового, который мы делали в 2010 году. Регулярные парки имели структуру четкую геометрическую, усадебный дом должен был располагаться на одной из главных планировочных осей, чего мы не имеем в Даровом. Флигель не попадает ни на какую ось. Сейчас липовой роще около 300 лет, это максимальный возраст липы. Может и до 400 дожить - у нас хорошие условия. Это возможно. Но всё равно нужно ее возобновлять. Липа сама по себе не возобновится, ее нужно подсаживать в наших условиях, и я благодарю волонтеров и сотрудников музея, которые подсаживают молодые липки в свободные пространства, образовавшиеся от упавших лип. 
Каким-то мемориальным липам можно сделать стяжку, пригласить для этого специалистов. Если пара деревьев наклонена, надо смотреть, чтобы она не упала, потому что две кроны удержать труднее. Возможно, понадобится подпорка стволов. Стволы лип со стволовой гнилью должны быть полыми, их нельзя заполнять пломбировочным материалом - они более устойчивы в этом случае, это принцип стебля одуванчика. То есть из дупла убирается гнилой материал, оно дезинфицируется и заделывается сверху щитком, который декорируется под кору. И дерево может простоять еще долго. Лучше, чем если его запломбировать и наполнить тяжелым материалом. И тогда мы сможем сохранить и возобновить нашу замечательную Липовую рощу.

Обязательно надо сохранять подлесок. Всё, что есть в подлеске сейчас, ни в коем случае нельзя вырубать, даже бузину (хотя она и прибаливает мучнистой росой), потому что это естественные спутники липы. Ее подлесочные породы: бузина, черемуха, орешник (лещина), которых сейчас тут много. Сохраняем максимально весь подлесок, он будет еще и держать хорошо нашу рощу, потому что стоит его выбрить - всё повалится мгновенно. Это единый организм - геобиоценоз. Крапиву мы убрали - и отлично, но подлесок надо сохранить.

Предложение по поводу экскурсионного маршрута по роще, который сейчас есть. Он имеет в плане замкнутую структуру, маршрут ознакомительный, его надо оставить. Покрытие лучше сделать мягким, поскольку никаких дорожек во времена Достоевских не было, они были естественными, грунтовыми, в лучшем случае посыпали песочком. Даже для этого, думаю, у Марии Федоровны не было времени, чтобы этим заниматься - очень много хозяйственных дел. Предлагаемое для маршрута покрытие мягкое: гранитный отсев красного цвета или песочек.

Любимая Федина роща - березовая. Береза - недолговечная порода, 100 лет - ее максимум, в 80 лет она уже сильно ослаблена и склонна к выпадению. Березу надо восстановить, волонтеры уже это делают. Сейчас ее пока мало, вместо нее пришли липа, клен и осина. Надо и дальше подсаживать березу и вырубать широколиственные породы, особенно клен вырубать. Следует сохранять напочвенный покров. Крапива - хорошо, что ушла, в липовых лесах преобладали широколиственные травы. Это та же самая нелюбимая 
нами сныть и другие травы. Ту траву, которая там сейчас есть, нужно сохранять, ни в коем случае не делать газон, как в городских парках.

К.В. Кондратьев. Где в каком углу были огороды и так далее, давайте вы проговорите отдельно. Я просто хочу обратить внимание всех, что это объект культурного наследия, и пока нет проекта реставрации, всё это - рекомендации, которые мы не имеем права выполнять. Проект будет подготовлен в этом году. Мы уже с вами говорили, что мы соберем отдельно экспертов по этому поводу. По части рощи я еще раз хочу напомнить, что в период существования помещичьих экономий в парках, рощах всегда осуществлялся выпас скота, поэтому там не могло быть того, что есть сейчас. Это в принципе невозможно, потому что скотина всё выедала. Это нормальная ситуация, характер усадебного межевого рва...

А.С. Бессонова. Я же Вам прогон коровий показала...

К.В. Кондратьев. ...характер межевого рва показывает как раз на это. Это нормальная практика. Не круглый год выпас осуществлялся, не забывайте про это. Соответственно, мы ждем проекта по сохранению этой территории, потому что сейчас официально органом охраны памятников Московской области после прошлогоднего составления акта технического состояния на объект «Усадьба Даровое» музею запрещено проводить какие-либо мероприятия по роще.

Л.А. Воронкина. В прошлом году был такой неудачный пример, и по моей просьбе его аннулировали: посадили орех грецкий. Ну, показалось, что это хорошо. Но это экзот, который ни в коем случае здесь недопустим. Была посажена сирень венгерская, ну пусть уж она останется, хотя это парковая порода, здесь ее не было. Поэтому никакой самодеятельности не должно быть, всё необходимо согласовывать со специалистами

В.А. Викторович. Пожелания и рекомендации высказываются сейчас будущим проектировщикам. Мне кажется, что пора уже определить стратегическое видение: что такое Даровое, что мы ожидаем увидеть под названием «Музей-заповедник Даровое». Очень важно - и мы не можем эту работу не поддерживать - то, что делают археологи, что делают архивисты. План усадьбы, строения, которые могут быть найдены. Но дело в том, что усадьба Даровое - это некий комплекс, в котором не строения, может быть, главную роль играли, а все-таки ландшафт. Мальчик Федя был здесь счастлив не потому только, что имелся скотный двор. Он был счастлив главным образом потому, что здесь была роща, здесь был ландшафт незабываемый, 
который вошел в него, в его творчество. Мы должны понимать, что будущий музей захватывает всю территорию обозримую, а не только вот этот дом и прилегающие хозяйственные постройки. Роща, пруд, поля, храм, о котором мы не говорим, я понимаю, он не в ведении музея, но всё это в комплексе должно работать, в комплексе производить целостное впечатление.

Поскольку о домах, о строениях много говорилось, я вернусь на своего любимого конька, за которого меня обвиняли, что мы, мол, хотим деревья ленточкой повязать и показывать. Роща и храм - не устаю повторять - это то, что бесспорно осталось нам от Достоевского, что несет в себе память о нем. Дом, как ни крути, перестроенный... А роща и храм безусловно, вещественно подлинные. Если говорить о роще, вот Кирилл Вячеславович утверждает: скотина в роще гуляла - и сейчас мы давайте тоже запустим ее. Я утрирую немного, уж позвольте. Но это опять же гипотеза, то, что вы говорите. При скотине не было бы никакого подлеска, да и в таком «скотском» лесу вряд ли заигрывались бы юные Достоевские. Усадьба детства или хоздвор, чего мы хотим?

Абсолютно согласен с Л.А. Воронкиной насчет сохранения травяного покрова, давайте не пойдем по пути шахматовскому [музей А.А. Блока в Шахматове], когда в газончик всё превратили. Это легко сделать: косить ранним покосом - и все травки и цветочки, из которых сейчас наши университетские ботаники гербарии составляют, уйдут, и у вас будет ровненький газончик, как вот здесь сейчас [в первом саду, где проходило заседание]. Мы ведь от этого много что потеряем. Вы говорите: а мы не знаем, какой тогда был травяной покров. Не знаем. А природа знает, природа сама себя регенерирует, природа сама является памятником. Да, она уже немножко изменилась с тех пор. Но давайте не будем навязывать ей каких-то своих представлений и законов. Это ж такая удача, что второй сад уникален по своей растительности. И пусть он останется. Я буду очень сожалеть, если вы там такой же регулярный сад разведете, как здесь. Там старые деревья, старые яблони стоят, которыми наши московские волонтеры [Андрей и Алексей Романовы, школьные учителя] очень много и с любовью занимались. Яблони на цветущем лугу очень живописны, очень красивы. Такое чудное приволье. Один из наших американских друзей-достоевистов упал там на траву и говорит: «Вот! надо же какое место было у Достоевского!» 
Природа лучший художник, и не надо ее «улучшать», навязывать какие-то наши сомнительные представления о том, что там якобы было. Возвращаясь к роще. Если мы сейчас будем вычищать этот подлесок - я опять же много раз говорил об этом - птички улетят. Вам не жалко? Конечно, вы можете провести птичий фестиваль и привезти на него попугайчиков, но ведь важно показать птичек, которые здесь живут и поют со времен Достоевских (и он их слышал!). Здесь же такое по весне творится, хорал птичий. Нам орнитолог описание сделал и говорит: «Боже мой, каких только птиц у вас нет!» Это богатство, которое у Достоевского было. И если мы позволим неким проектировщикам сделать здесь парк, вычистить подлесок птички улетят.

А.С. Бессонова. Птицы лечат рощу. Птицы - это здоровье рощи.

В.А. Викторович. Да, и плюс здоровье рощи. Также и подлесок сохраняет деревья. Проектировщики проектировщиками, но и мы, многие годы занимающиеся усадьбой, должны как-то контролировать, научные требования предъявлять, чтобы они не превратили это в парк культуры и отдыха.

О строениях. Может быть, мы ищем то, чего никогда не найдем. Следы пожара исчезли, но пожар-то был, мы точно это знаем. Та же самая мазанка - следов мы тоже можем не найти, но опять же мы точно знаем, что она была, как пишет Андрей Михайлович Достоевский, между двумя курганами. На том месте печку археологи раскопали в 2009 году, и Александр Сергеевич Сыроватко говорит: нет, не то, там гнутые гвозди... Ну понятно, что эту печь могли на месте мазанки уже в советские времена построить. И тогда какие следы от мазанки? Да так мы ее никогда не найдем! И в данном случае надо просто довериться Андрею Михайловичу, что вот здесь она была. Не обязательно ее строить. Может, вообе по минимуму надо здесь строить. Я даже рад был услышать, что мы не имеем права здесь ничего строить, потому что нет датированных фундаментов мемориального периода. Ну нет - и не надо. Давайте строиться рядом, конечно, музею это необходимо. Есть дома крестьянские рядом, и есть реальная пока возможность их купить: как минимум два дома напротив, где на задах можно отстроить служебные помещения для музея (невидимые от красной линии), еще дом крестьянский столетний ближе к пруду, готовый музей крестьянского быта. Нужно тактично вживаться в околоусадебное пространство, работать с местным населением. 
А здесь пусть оно вот так вот и остается. Место-то красивое само по себе. И чего мы тут будем городить еще? Просто надо людям как-то объяснять, что красота здешняя - та самая, она не столько в зданиях, сколько в окружающей природе. Мы всё время на этом настаиваем, что это должен быть музей той самой русской природы, которая вошла в Достоевского, в его сознание. Поэтому я и твержу: сохранение ландшафта, сохранение рощи, сохранение сада, покрова травяного.

Еще один момент, очень коротко. Нечаевский погост тоже требует заботы, ведь там захоронения XVIII века, это то, что Достоевский наверняка видел. Этот погост надо включать в план, причем в ближайший план. Игорю Ивановичу [Трушину, сотруднику музея] отдельное спасибо надо сказать, я и в прошлом году говорил это, и в этом повторю: он работает здесь за десятерых. И замечательно работает, хотя нужно еще какое-то научное обоснование, но у него сил не хватает. На Федину рощу не хватает. А Нечаевский погост несколько лет назад мы с волонтерами расчищали, а сейчас туда не ходим, и он зарос. А это же очень важная точка. Там была часовня, которую обязательно надо восстановить, она будет ориентиром, ключевым знаком этого пространства - этот храм деревянный, который там был. Понятно, что это будет новодел, но он будет организовывать всё пространство, как прежде, при Достоевских. Еще раз говорю, что музей Дарового - это пространство, которое должно быть здесь организовано и производить впечатление.

К.В. Кондратьев. Я не хочу изничтожить птичек. И птичий фестиваль был на самом деле придуман именно для того, чтобы приглашать в рощу, а не для того, чтобы завезти сюда птичек и показывать не тех, что в роще. Мы, наоборот, зовем всех в рощу, чтобы там слушали птичий концерт. Я к тому говорю, что есть понятие памятник как объект культурного наследия, который нужно сохранять, а есть памятник, который нужно музеефицировать. Это немножко разные вещи. У нас с вами стоит задача музеефицировать этот объект культурного наследия, потому что мы сейчас закончим косить-пилить - и здесь будет такая романтическая запущенность, и мы будем говорить о красоте русской природы и т.д. и т.п., которую Достоевский не видел в таком виде в этом месте. Опять-таки, я не настаиваю ни на чем ни в отношении парка, ни в отношении сада. Мы сейчас стараемся делать необходимый минимум. Будет проект, на него будет составлена государственная историко-культурная экс- 
пертиза, там всё это будет прописано. Экспертов три. Я думаю, что из сидящих за этим столом мы экспертный состав не наберем.

А.С. Бессонова. У нас есть эксперт, который в теме, Л.А. Воронкина.

К.В. Кондратьев. Я не против, мы уже поговорили, мы соберемся, когда будет контракт. Будет экспертиза, будут эксперты, всё сделают, и мы начнем работу. Мы пока набираем материал, и ценность нашей работы как раз в том, что мы пытаемся собрать материал об усадьбе - с чего мы начали, о которой, как выяснилось, мы практически ничего не знаем. И пусть будет это разнотравье. И пусть будут птички, белки, зайцы и прочая «скотинка». Мы пока говорим о той территории, которая закреплена за музеем. У нас есть территория, та, которая здесь есть, поручение музеефицировать, и давайте исходить из тех возможностей, которые у нас есть. Поэтому мы формируем идеи поэтапно, как положено: проекты, реализация этих проектов, с необходимыми экспертизами и т.д. Объект культурного наследия федерального значения. У нас с вами прибавился еще один объект культурного наследия: был выявлен объект культурного наследия археологический культурный слой усадьбы Даровое, который мы тоже обязаны сохранять в соответствии с Законом об объектах культурного наследия.

П.Е. Фокин. Владимир Александрович [Викторович] много мыслей здравых высказал, которые я разделяю. С другой стороны, есть вещи, которые мне не понятны. Почему, Владимир Александрович, вы допускаете возможность новодела часовни и говорите, что она будет держать пространство, при этом не допускаете возможность новодела на усадьбе, реконструкции, скажем так. Другой вопрос, что это проблематично: надо найти основание. Надо понимать, можно ли это сделать. Понимаете, да, Достоевский, приезжая сюда, в Даровое, открывает для себя мир русской природы замечательный, но он равно открывает мир и крестьянской... барской усадьбы, и вот эти сложные социальные отношения, которые так драматично отразятся в его судьбе - и через судьбу отца, и через его вот эти гражданские впечатления и обсуждения 40-х годов, которые приведут его на эшафот. И эти впечатления - они рождались не на голом месте, они рождались в этой деревне, в этой усадьбе. И в том числе эти хозяйственные все постройки - они точно так же вокруг себя формировали социальное пространство, в котором Достоевский жил. И этот мужик Марей - он не из земли вырос, он не из пахотного поля вышел. 
Поэтому если мы говорим о музейном каком-то объекте, не только музеефицированном, музейном объекте с последующей реконструкцией... у нас везде реконструкция, во всех наших музеях. Мы 200 лет спустя этим делом занимаемся, поэтому, естественно, не может быть всё аутентично. Но те, кто был в Михайловском, представьте себе Михайловское без пушкинского дома. Вот что это будет за музей? Да, прекрасный ландшафт и фантастическая природа. Но без этого дома начинает разрушаться это пространство. Потому что тогда: а где Пушкин жил? Да. Он скакал по этим просторам, ездил в гости в Тригорское и проч., и проч., но всё равно у него должно быть место. И мы знаем: это пятый дом, который на месте пушкинского построен. Хвала создателям этого дома, потому что, когда они его делали, они нашли действительно документы подлинные, которые позволили его максимально аутентично восстановить. В Даровом проблема сложнее, потому что нет этих документов, нет зарисовок, в Михайловском у них есть рисунок, который как-то более-менее позволяет ориентироваться на то, как была усадьба организована. Но мы не должны еще забывать и о посетителях. Потому что музей - это не просто объект, это еще и место посещения людей, которые... Человек - он так устроен... Вот вы сказали: часовня... И дом он тоже хочет барский видеть, как и часовню. И дом тоже будет организовывать это пространство. Другое дело, что, я в десятый раз это повторяю, здесь это чрезвычайно сложный вопрос, и действительно здесь должны работать эксперты и искать еще какие-то источники, документы, которые могли бы позволить эту реконструкцию сделать.

В.А. Викторович. Так разве я говорил, что не надо дом реконструировать? Конечно, надо. Он должен быть в границах по фундаменту примерно до березы восстановлен однозначно. Это, конечно, будет центр музейного пространства, так же как, кстати сказать, и храм моногаровский -второй центр мемориального ландшафта. Что касается часовни, то конечно это будет новодел. Я не в принципе против новодела, однако сначала надо найти фундамент бывшего нечаевского храма. Мы предполагаем с очень большой долей вероятности, где стоял этот деревянный храм (возвышение, на котором сосредоточены самые ценные надгробия), и он будет виден от усадьбы - вот о чем речь. Понятно, что при Достоевских там уже не служили, была часовня... Она ведь вошла в воспоминания Андрея Михайловича [Достоевского] как место детских интересов. Поэтому я и говорю, что она идейно и эстетически будет организовывать 
пространство, хотя понятно, что это будет новодел. И хозяйственные строения, как они показаны в исторических планах, тоже будут новоделы по типологии.

П.Е. Фокин. Меня смутило то, что вы говорите. Что на усадьбе ничего нельзя ставить.

В.А. Викторович. На жилой усадьбе вблизи дома да, кроме того, что уже есть, нельзя, по-моему.

П.Е. Фокин. Речь идет о том, что нельзя ставить новых, а в пределах тех фундаментов, которые возможно будет восстановить, можно строить.

В.А. Викторович. Понимаете, тут вопрос-то еще в чем? Мы еще в старых тех раскопках фундаменты открывали, но археологи однозначно говорят, что это поздние, это ивановские, так же, как и колодец. Нам не надо ивановские дома восстанавливать. А других-то и нет. Только центральный флигель можно расширить, и всё.

К.В. Кондратьев. Еще год тому назад мы говорили, что другие постройки могут быть, а сейчас мы увидели, что их нет. Исходя из этого и будем планировать дальше. Для этого мы проводим работу. Потому что вот это 50 на 50 - может, есть, а может, нет - у нас был бесконечный разговор о том, что мы можем в этом, например, углу что-то восстановить или нет. Давайте подумаем, есть ли тут что-то, что можно воссоздавать. Мы сейчас понимаем, что и воссоздавать [на территории, закрепленной за музеем] нечего.

В.А. Викторович. Вот археологи нашли колодец. Надо его? Мне кажется, что не надо: он Ивановых, а не Достоевских.

К.В. Кондратьев. Давайте закончим комплексные работы. Сейчас я не скажу ни «нужно», ни «не нужно». Будет обработан материал, который был там обнаружен, мы получим отчет, потому что должна пройти «камералка», эксперты, в том числе нумизматы, тоже должны посмотреть, всё нужно почистить и уже исходя из этого... давайте не будем требовать от археологов чего-то такого, что они не могут сказать точно. Пусть будет научный отчет о проведении раскопок, и тогда будет понятно. Пока мы говорим о том, что некие объекты обнаружены. Ивановы, Хотяинцевы, Достоевские - трудно сказать. Мы сейчас собираем материал в том числе и для создания макетов. Никто же нам не запрещает в экспозиции сделать, например, макеты усадьбы на эпоху Хотяинцевых, на эпоху Достоевских, на эпоху Ивановых и т.д. И для этого всего тоже нужны натурные исследования. Мы не можем построить ничего нового. И выдавать постройку 
Ивановых за постройку Достоевских тоже не хочется. У нас точно нет такой задачи, чтобы кого-то обмануть. Поэтому ищем, дружно ищем, и практика показывает, что надо искать дальше.

В.Н. Захаров. Виртуальные экспозиции, я думаю, могут очень многие проблемы решить, потому что жили помещики Достоевские тесно, бедно, без комфорта, все ютились в небольших комнатах, Федя бегал по лесам, гулял по полям, играл с крестьянскими детьми и проводил целые дни на природе. Я думаю, что на природе нам и нужно сосредоточиться в первую очередь. На некоторые вещи уже смотришь со страхом. Вот здесь яблоневый сад посадили. А красивая была поляна. Дай Бог, если всё красиво вырастет лет через $10 . .$.

В.А. Викторович. Насчет посадки деревьев. Кирилл Вячеславович я, конечно, понимаю вашу подневольную ситуацию, но, может, давайте какой-то компромисс найдем. Вот мы больше десяти лет сажали в роще липы, уже большие выросли, мы, конечно, следовали рекомендациям высокопрофессиональных дендрологов, но сажали, как бы это сказать, не согласуя своих действий с высокими кабинетами. Но представляете, если бы мы всё согласовывали, там бы их не было сейчас, уже больших и закрывающих пустоты от умерших деревьев. Пока проект, пока бесконечные, изматывающие проволочки... давайте, волонтеры посадят, а вы как будто не знаете про это. А если узнаете, тогда Игорь Иванович придет с бензопилой и все наши... за пять минут. Это же очень легко делается.

К.В. Кондратьев. У нас сейчас задача сохранить те объекты, которые есть. Поэтому никакого противоречия здесь нет. Есть объекты, которые дошли до нас, и нам их нужно сохранить дальше. По вопросу музеефикации - это проблема для музея, потому что музеефицировать нужно, нужна зона приема посетителей. Музей - это не только экспозиция, музей - это еще и необходимая инфраструктура: где-то должен храниться инвентарь, где-то люди должны нормально ходить в туалет, должен быть гардероб и т.д., это стандарт любого музея. Практика показывает, что нужен еще пункт приема питания и т.д. и т.п. Для нас сейчас проблема: мы не понимаем, как это сделать и где это всё разместить, хотя бы элементарный минимум.

В.Н. Захаров. Я тоже склоняюсь к тому, что нужно искать неординарные решения... Допустим, засевать, сажать то, что было при Достоевских и уже само по себе имеет и историческое, и эстетическое, художественное значение. Действительно, природа совершенна, и чем меньше мы будем вмешиваться, тем, я думаю, лучше. Лучше 
не сажать, а подсаживать, сохранять. Мне кажется, что все наши фантазии, проекты, гипотезы лучше проверять не на земле, а в виртуальном пространстве. Я за то, чтобы были виртуальные проекты, и могу даже предложить, если есть такое желание, подавать заявки в фонды. РФФИ такой проект поддержит. Я надеюсь, что виртуальная экспозиция будет размещена на сайте Литературного музея.

К.В. Кондратьев. Я вам хочу напомнить, что такое музей. В соответствии с законом о музейном фонде и музеях в Российской Федерации, музей - это некоммерческое учреждение культуры, которое хранит, собирает, комплектует, показывает предметы музейного фонда. А они виртуальными быть не могут. Поэтому если мы говорим о музее, для музея в первую очередь и самое главное - элемент подлинности. Без подлинного предмета не будет экспозиции. Виртуальное же может быть в качестве дополнения, и мы говорили, кстати, во время семинара директоров литературных музеев с Павлом Евгеньевичем [Фокиным] по поводу некоей виртуальной платформы, которая объединит все музеи Достоевского и позволит, если человек приедет сюда, увидеть и московский, и петербургский, и старорусский музеи...

В.Н. Захаров. В режиме реального времени демонстрировать их состояние.

К.В. Кондратьев. Это может быть проекция, информация, вариантов на самом деле очень много, и техника всегда идет вперед. Тем не менее элемент подлинности, в том числе наличие подлинников в экспозиции, всё равно должен сохраняться, без него музей перестает быть музеем. Это может быть что-то вроде Эксплораториума, это может быть просто консервация. Мы, например, объект законсервировали, и дальше он живет своей жизнью в виде живописной руины, условно говоря. И здесь речь идет как раз о том, что если мы его музеефицируем, то музей здесь в каком-то виде всё равно должен присутствовать.

В.Н. Захаров. Одно не отрицает другое. К сожалению, слишком много историй, когда реставраторы уничтожали памятники. В том числе и знаменитейшие.

Н.А. Костина. Наверное, все музейщики, которые здесь присутствуют, согласятся с тем, что вообще музей - это немножечко миф. Мы четко знаем, что было не так. Вот Борис Николаевич [Тихомиров] говорит: мы знаем, что Анна Григорьевна спала там-то. Но если поставим эту кровать, то... что смотреть?.. Одни кровати... Поэтому 
мы всё равно придумываем. И хотя мы знаем, что абсолютно точно было не так, но мы говорим: а вы знаете, вот было так. И это надо людям, которые приходят, обыкновенным людям, мы для них проводим экскурсии. Исследователи Достоевского знают, как оно было на самом деле, и будут долго и упорно спорить. А простой человек приходит и говорит: вы мне скажите точно: вот Ф.М. за это держался? - Держался! - Я удовлетворен! Без этого осязания реального человек не существует. Виртуальные вещи, которые у нас развиваются активно, интересны и забавны. Но мне все-таки ужасно хочется сказать: вот за этот стульчик Мария Федоровна держалась. И через пять лет буду говорить: точно, держалась. Да что вы говорите?! Мы немножко всегда придумываем, всегда создаем легенду.

В.А. Викторович. Немножко...

Н.А. Костина. Да. А у вас подлинное - вот оно вокруг. Может быть, здесь дерево стояло на три метра дальше, но точно липа. И точно дуб. И точно клёники. И точно были кусты - малина, смородина, я не знаю, еще что-то. И потом представьте, мы говорим о подлинности вещей: через 300 лет многие вещи вообще рассыплются - ткани, книги, еще что-то, их не будет. И будут просто наши потомки делать копии и говорить: вот точно такая же, и щербиночка такая же тут была. Наличие новодела в усадьбе вполне допустимо, почему нет? Я вообще смутно подозреваю, что у крестьян полы были земляные. Потому что Андрей Михайлович пишет: скотину кормить нечем, крыши соломенные сняли... Представляете, как бедно жили? Да и господский дом, я думаю, мазанка тоже с земляными полами: пришли, половики какие-то там постелили или рогожи, а на этих рогожах соломенные тюфяки - детей вповалку уложили. Тюфяки свернули, в сундуки сложили - всё, у нас теперь гостиная. Мы всегда немножко быт такой простой дворянской семьи, как Достоевские, приукрашиваем. И наш музей [в Старой Руссе] приукрашивает, но мы честно говорим: было немножко не так, было проще, скромнее, деревенскее. Так что и тут, может быть, совершенно простая усадьба. И человеку, пришедшему сюда, конечно, хочется увидеть, я не знаю, и колодец какой-то, и собачью будку...

В.Н. Захаров. Мы с вами очень много говорили о согласованности работ, исследований. Я думаю, что мы должны каким-то образом хотя бы нашим круглым столом рекомендовать нашим археологам согласовывать планы, действия на основе архивных материалов. Я должен сказать, что эти находки, которые демонстрировались 
сегодня на экране, попали в отчет РФФИ президенту. Говорили мы и о проблеме доступа к документам в архивах, и о проблемах, которые возникали с выполнением источниковедческих проектов. Я думаю, что мы поручим присутствующим здесь членам Оргкомитета [по подготовке и проведению празднования 200-летия со дня рождения Ф.М. Достоевского] обратиться с просьбой об облегчении доступа в архивы и другие хранилища. Конечно, музей нужно создавать, сведя к минимуму конфликты с местным населением. Я думаю, что это должно быть общим делом и общей заботой. Чтобы объяснить и найти какие-то слова, должны действовать не только какие-то государственные структуры, административные институты, нужно будет встретиться и поговорить с жителями ученым, деятелям культуры, чтобы они объяснили, что такое Даровое, кто Достоевский в современном мире.

К.В. Кондратьев. Что ж, будет проект, и мы будем его обсуждать. Я просто жду, когда появятся проектировщики, чтобы все собрались и на них набросились! Наша общая задача как некоего экспертного сообщества, сделать так, чтобы продукт, который получится в итоге, получился качественным. И в том числе ради этого мы сегодня здесь собрались.

\section{$* * *$}

На момент подготовки к печати данного материала работа археологов в ее камеральной части еще не была завершена, однако некоторые итоги уже имеются. Наиболее активный культурный слой, как выяснилось, располагается вокруг существующего усадебного дома, он-то и должен стать центром музейного пространства при обязательном восстановлении утраченной части дома - его границы определены археологическими исследованиями.

Одно обстоятельство сильно смущает наших коллег-археологов: все найденные в раскопах предметы датируются либо второй половиной XVIII, либо второй половиной XIX века, что закономерно: хронологические рамки жизни в Даровом Хотяинцевых и Ивановых неизмеримо шире тех 7 лет, что связаны с пребыванием здесь Ф.М. Достоевского и его родителей. Непосредственно от 1830-х годов никаких следов вокруг усадебного дома не обнаружено. Следовательно, говорят нам, дом Достоевских был в другом месте, вероятно, ближе к пруду, на застроенной сейчас территории. Выскажем свои контраргументы. 
Во-первых, вещи XVIII века не изымались из обращения после 1 января 1800 года и могли служить потомкам, в особенности ценные. Так что «статусные» и «старинные» предметы вроде тех, что найдены археологами вблизи существующего дома, могли быть и в семье Достоевских ${ }^{12}$.

Во-вторых, земля от сохранившегося дома до пруда могла быть жилой усадьбой лишь до межевого рва, остатки которого просматриваются не так далеко от дома. Очевидно, этот ров и был границей помещичьего жилья. Все вещи, которые обнаружили за пределами рва и сохранили местные жители - семья Макаровых (отдельное им спасибо!), относятся исключительно к хозяйственной деятельности. Среди них, кстати говоря, есть предметы, точно датируемые временем Достоевских. На нахождение этих земель вне жилой зоны помещичьей усадьбы указывают и выявленные в этом году архивные документы по выкупным делам 1860-х годов, о чем подробно говорилось на конференции. Кроме того, у нас всё-таки нет оснований не доверять «Воспоминаниям» А.М. Достоевского: он временами неточен в плане хронологии, но не топографии. Господский дом, по его словам, стоял в Липовой роще, которая вплотную подходила к нему. Обсаженные с четырех сторон липами «курганы» - тоже вблизи господского жилья. Почему-то эти датирующие «артефакты» упорно игнорируются археологами. Как и то, что планировка усадьбы, включая все межевые валы - один из важнейших ориентиров, сохранилась до наших дней, Липовая роща не поменяла своего местоположения. Существует, в конце концов, традиция усадебного строительства и здравый смысл, который говорит, что в нашей ситуации только междисциплинарные исследования способны дать объективную картину.

В сохранившемся доме доживала свой век последняя владелица усадьбы Мария Александровна Иванова, племянница писателя. у нее, судя по всему, не было никаких сомнений в подлинности родового, «дедовского» дома (единственного на всем пространстве усадьбы основательно стоящего на ленточном фундаменте) $)^{13}$. Другое дело, что он был перестроен еще в 1880-е годы. Насколько аутентично нынешнее строение, могло бы сказать дендрохронологическое его обследование. О необходимости такового мы говорим уже не

12 Об этом мы писали еще в 2013 году: [Бессонова, 2013, с. 163-164].

13 См. подробно статьи 1920-х годов А. Дроздова, Л. Гроссмана, И. Перлова, В. Нечаевой, Д. Стонова о посещении Дарового: [Даровое]. 
первый год, а воз и ныне там. Надо провести археологические исследования и внутри дома. Без наших общих научных усилий проект реставрации будет сильно «хромать».

\section{Список литературы}

1. Айоади, 2014 - Айоади Р. Вопрос о том, что на самом деле является двойником // Известия. 2014. 29 апреля. URL: https://iz.ru/news/570100 (дата посещения: 29.01.2020).

2. Айоади - Айоади Р. Это вам не пьеса Беккета. URL: https://www.filmpro.ru/materials/29610 (дата посещения: 29.01.2020).

3. Белинский, 1955 - Белинский В.Г. Полн. собр. соч.: в 13 т. М.: АН СССР, Ин-т рус. литературы, 1955.

4. Берберова, 2001 - Берберова Н.Н. Набоков и его «Лолита» // Берберова Н.Н. Набоков и его «Лолита». Чайковский. Железная женщина. Рассказы в изгнании. М.: Изд-во им. Сабашниковых, 2001. С. 650-671.

5. Бессонова, 2013 - Бессонова А.С. К вопросу о концепции музея-заповедника «Даровое» // III Летние чтения в Даровом. Коломна: ИД «Лига», 2013. С. 149-176.

6. Блок, 1997 - Блок А.А. Полное собрание сочинений и писем: в 20 т. Т. 3. М.: Наука, 1997. 994 c.

7. Булгарин, 1846 - Булгарин Ф.В. Всякая всячина // Северная пчела. 1846. 1 февраля. C. 107.

8. Воспоминания..., 1930 - Воспоминания Андрея Михайловича Достоевского / ред. и вступит ст. А.А. Достоевского. Л.: Изд. писателей в Ленинграде, 1930. 426 с.

9. Горький, 1956 - Горький М. Заметки о мещанстве // Ф.М. Достоевский в русской критике: сб. ст. М.: ГИХЛ, 1956. С. 388-389.

10. Горьковенко, 1999 - Горковенко А.Е. Достоевский в художественном сознании Набокова: автореф. канд. дис. М., 1999

11. Даровое - Заповедное Даровое. URL: http://darovoe.ru/publication/research (дата посещения: 29.01.2020).

12. Зарин, 1862 - 3-ъ <Зарин Е.Ф.> Небывалые люди (Униженные и оскорбленные. Роман Ф. Достоевского) // Библиотека для чтения. 1862. Т. 169. № 2. Современная летопись. С. 34 .

13. Кадыров - Кадыров И.М. «Двойник» Достоевского: попытка психоаналитической интерпретации. URL: http://psyjournals.ru/mpj/2002/n1/Kadyrov_full.shtml (дата посещения: 29.01.2020).

14. Карякин, 1989 - Карякин Ю.Ф. Достоевский и канун XXI века. М.: Советский писатель, 1989.652 с.

15. Набоков, 2007 - Набоков В.В. Лолита. М.: АСТ, 2007. 429 с.

16. Перлов, 1925 - Перлов И.П. Сельцо Даровое в жизни и творчестве Ф.М. Достоевского // По Тульскому краю. (Пособие для экскурсий). Тула: Издательство Тульского губисполкома, 1925. С. 521-527. 
17. Прохоров, 2014 - Прохоров Г.С. Что за музей был в Даровом в 1923-1929 гг. // Достоевский и мировая культура: Альманах. 2014. № 31. С. 329-344.

18. Пушкин. Лермонтов. Гоголь, 1952 - Пушкин. Лермонтов. Гоголь / Лит. наследство; Т. 58. М.: Изд-во АН СССР, 1952. 1059 с.

19. Сараскина, 1993 - Сараскина Л.И. Набоков, который бранится // Октябрь. 1993. № 1. С. $176-189$.

20. Соловьев, 1875 - Sine ira <Соловъев Bc.C.>. Наши журналы // Санкт-Петербургские ведомости. 1875. 1 февраля. С. 1-2.

21. Тимофеева, 1990 - Тимофеева В.В. (О. Починковская). Год работы с знаменитым писателем // Ф.М. Достоевский в воспоминаниях современников: в 2 т. М.: Художественная литература, 1990. Т. 2. С. 137-196.

22. Три критические статьи..., 1995 - Три критические статьи г-на Имрек // Аксаков К.С. Эстетика и литературная критика. М.: Искусство, 1995. С. 136-144.

23. Федоров, 2004 - Федоров Г.А. Московский мир Достоевского. Из истории русской художественной культуры ХХ века. М.: Языки славянской культуры, 2004. 464 с.

24. Шадурский, 2004 - Шадурский В.В. Интертекст русской классики в прозе Владимира Набокова. Великий Новгород: НовГУ им. Ярослава Мудрого, 2004. 95 с.

25. Шепелев, 2003 - Шепелев А.А. Ф.М. Достоевский в художественном мире В.В. Набокова. Тема нимфолепсии как рецепция темы «ставрогинского греха»: канд. дис. Тамбов, 2003

26. Шмелев, 1998 - Шмелев И.С. Собр. соч.: в 5 т. Т. 4. М.: Русская книга, 1998. 560 с.

27. Loygue, 1904 - Loygue P. Étude médico-psychologique sur Dostoïewsky, considérations sur les états morbides liés au génie. Lyon: A. Storck, 1904. 185 p.

\section{References}

1. Aioadi R. Vopros o tom, chto na samom dele iavliaetsia dvoinikom [The question of what is really a double]. Izvestiia [News], 2014, April 29. Available at: https://iz.ru/news/570100 (last accessed: 29.01.2020). (In Russ.)

2. Aioadi R. Eto vam ne p'esa Bekketa [This is not a Becket's play for you]. Available at: https:// www.filmpro.ru/materials/29610 (last accessed: 29.01.2020). (In Russ.)

3. Belinskii V.G. Poln. sobr. soch.: $v 13$ t. [Complete works: in 13 vols.]. Moscow, AN SSSR, In-t rus. literatury Publ., 1955. (In Russ.)

4. Berberova N.N. Nabokov i ego «Lolita» [Nabokov and his "Lolita"]. Berberova N.N. Nabokov i ego «Lolita». Chajkovskij. Zheleznaja zhenshhina. Rasskazy v izgnanii [Nabokov and his Lolita. Tchaikovsky. Iron woman. Stories in exile]. Moscow, Izd-vo im. Sabashnikovyh Publ., 2001, pp. 650-671. (In Russ.)

5. Bessonova A.S. K voprosu o kontseptsii muzeia-zapovednika "Darovoe" [About the question of the concept for a reserve-museum]. III Letnie chteniia $v$ Darovom [3 ${ }^{\text {rd }}$ Summer Readings in Darovoe], Kolomna, ID “Liga” Publ., 2013, pp. 149-176. (In Russ.)

6. Blok A. A. Polnoe sobranie sochinenii i pisem: $v 20$ t. [Complete works and letters: in 20 vols.]. Moscow, Nauka Publ., 1997. Vol. 3. 994 p. (In Russ.) 
7. Bulgarin F.V. Vsiakaia vsiachina [Miscellanea]. Severnaia pchela [The Northern Bee], 1846, February 1, p. 107. (In Russ.)

8. Vospominaniia Andreia Mikhailovicha Dostoevskogo [A.M. Dostoevsky's memoirs], ed. and prefaces by A.A. Dostoevsky. Leningrad, Izd. pisatelei v Leningrade Publ., 1930. 426 p. (In Russ.)

9. Gor'kii M. Zametki o meshchanstve [Notes of philistinism]. F. M. Dostoevskii v russkoi kritike: sb. st. [F. M. Dostoevsky in Russian critics: collected articles], Moscow, GIKHL Publ., 1956, pp. 388-389. (In Russ.)

10. Gorkovenko A.E. Dostoevskij v hudozhestvennom soznanii Nabokova [Dostoevsky in Nabokov's artistic consciousness], avtoref. kand. dis. Moscow, 1999. (In Russ.)

11. Zapovednoe Darovoe [Reserve-museum Darovoe]. Available at: http://darovoe.ru/publication/research (last accessed: 29.01.2020). (In Russ.)

12. <Zarin E. F.> Nebyvalye liudi (Unizhennye i oskorblennye. Roman F. Dostoevskogo) [Unheard-of people (The Insulted and the Injured. A F. Dostoevsky's novel)]. Biblioteka dlia chteniia [Library for reading], 1862, vol. 169, No 2: Modern Chronicle, p. 34. (In Russ.)

13. Kadyrov I. M. "Dvoinik" Dostoevskogo: popytka psikhoanaliticheskoi interpretatsii [Dostoevsky's The Double: an attempt of psychoanalytic interpretation]. Available at: http://psyjournals. $\mathrm{ru} / \mathrm{mpj} / 2002 / \mathrm{n1} /$ Kadyrov_full.shtml (last accessed: 29.01.2020). (In Russ.)

14. Karjakin Ju.F. Dostoevskij i kanun XXI veka [Dostoevsky and the eve of the XXI century.]. Moscow, Sovetskij pisatel' Publ., 1989. 652 p.

15. Nabokov V. V. Lolita [Lolita]. Moscow, AST Publ., 2007. 429 p. (In Russ.)

16. Perlov I. P. Sel'tso Darovoe v zhizni i tvorchestve F. M. Dostoevskogo [The village of Darovoe in F. M. Dostoevsky's life and works]. Po Tul'skomu kraiu. (Posobie dlia ekskursii) [About Tula region. Excursion textbook], Tula, Izdatel'stvo Tul'skogo gubispolkoma Publ., 192, pp. 521-527. (In Russ.)

17. Pushkin. Lermontov. Gogol', Lit. nasledstvo [Literary Legacy]; T. 58. Moscow, AN SSSR Publ., 1952. 1059 p. (In Russ.)

18. Prokhorov G. S. Chto za muzei byl v Darovom v 1923-1929 gg. [What kind of museum was in Darovoe in 1923-1929]. Dostoevskii i mirovaia kul'tura. Almanac [Dostoevsky and world culture. Miscellany], 2014, No 31, pp. 329-344. (In Russ.)

19. Saraskina L.I. Nabokov, kotoryj branitsja [Nabokov, who swears]. Oktjabr' [October]. 1993. № 1. pp. 176-189. (In Russ.)

20. Sine ira <Solov'ev Vs. S.>. Nashi zhurnaly [Our magazines]. Sankt-Peterburgskie vedomosti [Records from St. Petersburg], 1875, February 1, pp. 1-2. (In Russ.).

21. Timofeeva V. V. (O. Pochinkovskaia). God raboty s znamenitym pisatelem [One year of work with a famous writer]. F. M. Dostoevskii v vospominaniiakh sovremennikov: $v 2 t$. [F.M. Dostoevsky in his contemporaries' memoirs: in 2 vols.], Moscow, Khudozhestvennaia literatura Publ., 1990, vol. 2, pp. 137-196. (In Russ.)

22. Tri kriticheskie stat'i g-na Imrek [Three critical articles by Mr. So-and-So]. Aksakov K.S. Estetika i literaturnaia kritika [Aesthetics and literary critics], Moscow, Iskusstvo Publ., 1995, pp. 136-144. (In Russ.)

23. Fedorov G. A. Moskovskii mir Dostoevskogo. Iz istorii russkoi khudozhestvennoi kul'tury XX veka [Dostoevsky's Moscow world. From the history of the Russian artistic culture of the $20^{\text {th }}$ c.]. Moscow, Iazyki slavianskoi kul'tury Publ., 2004. 464 p. (In Russ.) 
24. Shadurskij V.V. Intertekst russkoj klassiki v proze Vladimira Nabokova [The intertext of the Russian classics in the prose of Vladimir Nabokov]. Velikij Novgorod: NovGU im. Jaroslava Mudrogo Publ., 2004. 95 p. (In Russ.)

25. Shepelev A.A. F.M. Dostoevskij v hudozhestvennom mire V.V. Nabokova. Tema nimfolepsii kak recepcija temy «stavroginskogo greha» [F. M. Dostoevsky in the art world of V.V. Nabokov. The theme of nympholepsy as a reception of the theme of " stavroginsky sin»], kand. dis. Tambov, 2003. (In Russ.)

26. Shmelev I. S. Sobr. soch.: 15 t. [Collected works: in 5 vols.]. Moscow, Russkaia kniga Publ., 1998. Vol. 4. 560 p. (In Russ.)

27. Loygue P. Étude médico-psychologique sur Dostoïewsky, considérations sur les états morbides liés au genie [Medical-psychological study of Dostoyewsky, considerations of engineering-related morbidity]. Lyon, A. Storck Publ., 1904. 185 p. (In French) 